University of Warwick institutional repository: http://go.warwick.ac.uk/wrap

This paper is made available online in accordance with publisher policies. Please scroll down to view the document itself. Please refer to the repository record for this item and our policy information available from the repository home page for further information.

To see the final version of this paper please visit the publisher's website. Access to the published version may require a subscription.

Author(s): Marshall, Peter

Article Title: The naming of Protestant England

Year of publication: 2012

Link to published article : http://dx.doi.org/10.1093/pastj/gtr030

Publisher statement: This is a pre-copy-editing, author-produced PDF of an article accepted for publication in Past \& Present, following peer review. The definitive publisher-authenticated version: Marshall, P. (2012). The naming of Protestant England. Past \& Present, 214(1), pp. 87-128. is available online at:http://dx.doi.org/10.1093/pastj/gtr030 


\section{The Naming of Protestant England ${ }^{*}$}

Peter Marshall

The writer Daniel Defoe, surveying two centuries during which his country had travelled 'from the Romish Religion to Reform'd, from Reform'd back again to $\underline{\text { Romish}}$, and then to Reform'd again', could note with satisfaction that 'the Name of Protestant is now the common Title of an Englishman'. ${ }^{1}$ How, and how quickly, England became Protestant, and English people became Protestants, in the course of the sixteenth and early seventeenth centuries is a longstanding and contentious historical question. ${ }^{2}$ In the late 1970s, Britain's leading Tudor historian, G. R. Elton, could confidently assert that by the end of the reign of Edward VI 'England was almost certainly nearer to being a Protestant country than to anything else' ${ }^{3}$ But it was already becoming clear that what Patrick Collinson has christened 'the birthpangs of Protestant England' were a more protracted and painful process. ${ }^{4}$ Revisionist scholarship of the 1980s and 90s stressed the slow and uncertain pace of reform, and the difficulty in securing conversions, with Christopher Haigh proposing, in an intriguing formulation, that even by the middle of Elizabeth's reign, the Reformation had succeeded in creating 'a Protestant nation, but not a nation of Protestants'. ${ }^{5}$ More recently, attention has shifted from measuring patterns of conversion to investigating political accommodations and negotiations on the part of rulers and ruled. ${ }^{6}$ Other

\footnotetext{
${ }^{*}$ The first version of this paper was written in June 2009 for a conference at the University of the West of England to honour the late Trevor Johnson, whose personal and academic inspiration over many years I should like to acknowledge here.

Subsequent drafts have been read and commented on, to my great advantage, by Tom Freeman, Mark Knights, Anthony Milton and Alec Ryrie.

${ }^{1}$ Daniel Defoe, An Enquiry into the Occasional Conformity of Dissenters in Cases of Preferment (Dublin, 1698), Preface, 8.

${ }^{2}$ For an overview of recent historiographical trends, see Peter Marshall, '(Re)defining the English Reformation', Journal of British Studies, 48 (2009).

${ }^{3}$ G. R. Elton, Reform and Reformation: England 1508-1558 (London, 1977), 371.

${ }^{4}$ Patrick Collinson, The Birthpangs of Protestant England: Religious and Cultural Change in the Sixteenth and Seventeenth Centuries (Basingstoke, 1988).

${ }_{5}^{5}$ Christopher Haigh, English Reformations: Religion, Politics, and Society under the Tudors (Oxford, 1993), 280.

${ }^{6}$ Ethan H. Shagan, Popular Politics and the English Reformation (Cambridge, 2003).
} 
studies of a broadly 'post-revisionist' character draw attention to transitions and continuities in religious culture across the putative Reformation divide. ${ }^{7}$ The 'Protestantism' of the English Church and its people is assumed, but the degree to which common understandings of it were shared by clergy and laity, and across social classes, remains deeply problematic. ${ }^{8}$

This essay contributes to the investigation of how, why, and when the people of England (or most of them) became 'Protestants'. Yet it is concerned not so much with socio-structural changes as with linguistic and nominal ones, while recognising that the processes are connected in crucial and interdependent ways. It sets itself the principal tasks of demonstrating how appropriations and deployments of the term 'Protestant' can be charted by historians of sixteenth- and early seventeenth-century England, and of asking why they should bother to do so.

'Protestant', it hardly needs saying, is a fundamental 'keyword' for the study of the Reformation. In popularizing the concept of keywords, the literary scholar Raymond Williams advocated a kind of cultural etymology, the importance of paying attention to the vital social and historical processes reflected within language and changing linguistic usage. ${ }^{9}$ In a subsequent critique, Quentin Skinner charged Williams with focusing too narrowly on the internal development and structures of keywords, and of neglecting the extent to which terms gain their meanings from the place they occupy 'within an entire conceptual scheme'. Crucially for my purposes, he also emphasised the dynamic role of social agents in appropriating and reshaping available and malleable terms in order to legitimize their own attitudes and activities. $^{10}$

\footnotetext{
${ }^{7}$ For example, Susan Wabuda, Preaching During the English Reformation (Cambridge, 2002); Christine Peters, Patterns of Piety: Women, Gender and Religion in Late Medieval and Reformation England (Cambridge, 2003); Robert Lutton and Elisabeth Salter (eds.), Pieties in Transition: Religious Practices and Experiences, c. 1400-1640 (Aldershot, 2007).

${ }^{8}$ For a lively and provocative presentation of divergent 'types' of Protestantism in Elizabethan and early Stuart England, see Christopher Haigh, The Plain Man's Pathways to Heaven: Kinds of Christianity in Post-Reformation England (Oxford, 2007).

${ }^{9}$ Raymond Williams, Keywords: A Vocabulary of Culture and Society (revised ed., London, 1985).

${ }^{10}$ Quentin Skinner, 'Language and Political Change', in Terence Ball, James Farr and Russell L. Hanson (eds.), Innovation and Conceptual Change (Cambridge, 1989), quotation at p. 13.
} 
Historians of early modern religion have not been entirely insensitive to issues around terminology and nomenclature. In the field of English Reformation studies, extremely valuable work by Patrick Collinson and Peter Lake has explored the origins of the derisory nickname 'Puritan', and the ways in which the phenomenon of Puritanism was 'constructed' in the later sixteenth century through patterns of stereotyping and name-calling, a theme to which this essay will return. ${ }^{11}$ Yet to date this type of analysis has not been extended very much to any of the other denominated identities of English religion in the Reformation period. ${ }^{12}$

In a seminal article of 1982, John Bossy insisted 'that words matter; that without a sense of their history they become manipulable in the cause of obfuscation', adding that 'the general principle must be to use the word as it was used by those we are writing about. ${ }^{13}$ Historians can hardly avoid anachronistic terminology altogether. But there are particular dangers in careless or unreflective use of religious and confessional labels. To talk about 'Roman Catholic' beliefs, practices, or structures in the Middle Ages, for example, is implicitly to endorse, sympathetically or otherwise,

${ }^{11}$ Patrick Collinson, 'A Comment Concerning the Name Puritan', Journal of Ecclesiastical History, 31 (1980); The Puritan Character: Polemics and Polarities in Early Seventeenth-Century English Culture (Los Angeles, 1989); 'Ecclesiastical Vitriol: Religious Satire in the 1590s and the Invention of Puritanism', in John Guy (ed.), The Reign of Elizabeth I: Court and Culture in the Last Decade (Cambridge, 1995); 'Ben Johnson's Bartholomew Fair: The Theatre Constructs Puritanism', in David L. Smith, Richard Strier, and David Bevington (eds.), The Theatrical City: Culture, Theatre and Politics in London, 1576-1649 (Cambridge, 1995);

'Antipuritanism', in John Coffey and Paul C. H. Lim (eds.), The Cambridge Companion to Puritanism (Cambridge, 2008). Lake has been at times critical of what he regards as Collinson's unduly 'nominalist' approach: 'Puritan Identities', Journal of Ecclesiastical History, 35 (1984); 'Defining Puritanism - again?', in Francis J. Bremer (ed.), Puritanism: Transatlantic Perspectives on a Seventeenth-Century Anglo-American Faith (Boston, 1993); (with Michael Questier), The Antichrist's Lewd Hat (New Haven, 2002), 568-70; 'The historiography of Puritanism', in Coffey and Limm (eds.), Companion to Puritanism.

${ }^{12}$ Some useful starting points, however, are: Herbert Thurston, 'The History of the Name "Roman Catholic", The Month, 118 (1911); Robert W. Shoemaker, The Origin and Meaning of the Name 'Protestant Episcopal' (New York, 1959); Thomas H. Clancy, 'Papist-Protestant-Puritan: English Religious Taxonomy, 1565-1665', Recusant History, 13 (1976). Clancy devoted just over 5 pages (233-38) to contemporary meanings of Protestant, but had little to say about origins or the timescale of diffusion. See also Peter Marshall, 'Is the Pope Catholic? Henry VIII and the Semantics of Schism', in Ethan H. Shagan (ed.), Catholics and the 'Protestant Nation': Religious Politics and Identity in Early Modern England (Manchester, 2005). ${ }^{13}$ John Bossy, 'Some Elementary Forms of Durkheim', Past and Present, 95 (1982), 17. 
a particular interpretation of Church history. ${ }^{14}$ It is not merely ironic to ask whether Luther was a Lutheran, or Calvin a Calvinist. ${ }^{15}$ Applied retrospectively, the names of later denominations can create teleological presumptions about patterns of development, sanitizing conditions of disorder or uncertainty, and obscuring pointers to paths not taken. Following Bossy's prescription, therefore, my essay aims to investigate how, and how frequently, the word Protestant was actually used by contemporaries in the sixteenth and early seventeenth centuries, and to track its shifting structural relationships with some other key terms of identity and attribution which we can regard as occupying a common 'conceptual scheme': Catholic, papist, evangelical, Puritan, Calvinist, Lutheran, Anglican.

A brief comment on methodology is in order here. While any historical investigation of the genesis and diffusion of new nomenclature demands wide and impressionistic reading, recent developments in electronic information retrieval systems have allowed a way of proceeding that would once have been merely illustrative to progress towards the diagnostic. In searching for Protestant/s and related terms I have made extensive use of the ever-expanding quantity of texts, and fully text-searchable volumes, available from Early English Books Online, as well as the State Papers Online, the Oxford Dictionary of National Biography, the online editions of John Foxe's Acts and Monuments, and the remarkable range of printed primary sources accessible, in whole or part, through Google Books. Such a procedure requires considerable caution. Calendars, for instance, insert the word 'Protestant' into summaries of original documents where the term does not itself appear. EEBO is not entirely comprehensive. Most of its volumes do not yet have keyed-in text, and some of those which do display errors in transcription. Arguments from silence are thus problematic. Nonetheless, it is now becoming possible to survey the textual and semantic landscape of early modern England in ways our scholarly predecessors could not have imagined. Undertaking this for the word Protestant and its conceptual cousins, I will argue, sheds significant light on religious controversies during the Reformation era, and provides new insight into some intricately transactional patterns of identity-formation.

\footnotetext{
${ }^{14}$ This has been, and remains, a widespread scholarly habit: the phrase 'medieval Roman Catholic' produces (as of Sep. 2010) hits in 2650 volumes in 'Google Books'. ${ }^{15}$ Cf Basil Hall, 'Calvin against the Calvinists', in Gervase E. Duffield (ed.), John Calvin (Abingdon, 1966).
} 
'Protestant' was an immigrant-word, but one that began to settle in England from the reign of Henry VIII. Its origins date to the 1529 Diet of Speyer, at which six German Lutheran princes and a number of allied towns issued a defiant 'protestatio' against Charles V's reinstatement of the repressive religious terms of the 1521 Diet of Worms. These dissidents, and the adherents of the broader pro-Luther movement in Germany, as a consequence began to be termed 'Protestants', though they usually referred to themselves by the name they had favoured throughout the $1520 \mathrm{~s}$, evangelisch or evangelical. ${ }^{16}$ The references one can find to 'Protestants' in English sources of the 1530s, and early-mid-1540s, are, without exception, to individuals and events in the German Empire. ${ }^{17}$ There is no evidence that home-grown reformers, William Tyndale and his ilk, were ever tempted to call themselves by that term. 'Protestants', in Henry VIII's England, were invariably foreigners, and when the old king was buried in January 1547, space was set aside in the funeral procession for 'Protestants... and other notable strangers'. ${ }^{18}$ The reign of Edward VI is conventionally regarded as having established 'Protestantism' in England, but, as a recent study of the writings of Edwardian reformers admits (with, I think, some understatement), they themselves 'rarely used the term'. ${ }^{19}$ Successive generations of historians of the early Reformation have in fact cheerfully slapped a label on their subjects that those historical agents seem never to have used about themselves. ${ }^{20}$

\footnotetext{
${ }^{16}$ Alister E. McGrath and Darren C. Marks, 'Introduction: Protestantism - The Problem of Identity', in McGrath and Marks (eds), The Blackwell Companion to Protestantism (Oxford, 2004), 2.

${ }^{17}$ Peter Marshall and Alec Ryrie, 'Introduction: Protestantisms and their Beginnings', in Marshall and Ryrie (eds), The Beginnings of English Protestantism (Cambridge, 2002), 5 .

${ }^{18}$ Cal. St. P. Dom. Edward VI 1547-1553, no. 16. The same was true of the coronation procession of Edward VI: Diarmaid MacCulloch, Tudor Church Militant: Edward VI and the Protestant Reformation (London, 1999), 2.

${ }^{19}$ Catharine Davies, A Religion of the Word: The defence of the Reformation in the reign of Edward VI (Manchester, 2002), xx.

${ }^{20}$ For example, William A. Clebsch, England's Earliest Protestants 1520-1535 (New Haven and London, 1964); John Fines, A Biographical Register of Early English Protestants, c. 1525-1558 (2 vols., Abingdon, 1981-85).
} 
Scholars have for some time been aware of this anomaly. In a pioneering study of early Tudor court humanism, Maria Dowling noted the anachronism of using 'Protestant' to describe those subjects of Henry VIII who favoured innovations in doctrine, and proposed instead to call them 'evangelicals' or (a label they themselves preferred) 'upholders of the gospel'. ${ }^{21}$ Evangelical is not free of interpretative difficulties, and it seems to have been a term employed as much by their enemies as by the reformers themselves. ${ }^{22}$ Some scholars worry about its own anachronistic resonances of modern Christian evangelicalism, and others simply continue to call early Tudor reformers Protestants in a no-nonsense sort of way. ${ }^{23}$ Nonetheless, in addition to being an authentically contemporary term, evangelical captures well what united a broad spectrum of dissidents and reformers - an emphasis on a transformative encounter with the gospel - while preserving a sense of the fluidity and diversity characterising the early reform movement, and the wide range of doctrinal positions to be found within it. ${ }^{24}$

${ }^{21}$ Maria Dowling, Humanism in the Age of Henry VIII (Beckenham, 1986), 'Note and Acknowledgments'. Dowling credited the suggestion to David Starkey, whose The Reign of Henry VII: Personalities and Politics (London, 1985) generally referred to court 'evangelicals', though he speculated (p. 121) that some members of Henry's Privy Chamber were 'perhaps even Protestants'.

${ }^{22}$ Thomas More had a particularly practised sarcastic line of reference to 'evangelical brethren' and 'evangelical liberty': The Confutacyon of Tyndales Answere (London, 1532, STC 18079), 75, 199, 299; The Second Parte of the Confutacion of Tyndals Answere (London, 1533, STC 18080), 172, 193, 204, 234, 376, 393, 426, 429, 472, 474, 487, 504; The Apologye of Syr Thomas More Knight (London, 1533, STC 18078), 13, 15. Elsewhere More complained of his opponents arrogantly appropriating for themselves the name of evangelicals, but conceded that it was 'now, and some yeres al redy passed hath ben, the name by which they haue bene as commenly called'. He insisted, however, that the name was used by Catholics 'not to theyr prayse, but to theyr rebuke \& shame', just as St Augustine had called Manicheans $\underline{\text { Cathari, }}$ pure ones, while exposing their shameless living: The Debellacyon of Salem and Bizance (London, 1533, STC 18081), fos. 29r-30v.

${ }^{23}$ See Joseph S. Block's review of my Religious Identities in Henry VIII's England, in Journal of British Studies, 46 (2007). Protestant is the term deployed throughout Eamon Duffy, The Stripping of the Altars: Traditional Religion in England 1400-1580 (New Haven and London, 1992); Haigh, English Reformations, uses the words interchangeably in reference to the early Reformation period.

${ }^{24}$ Recent studies making the case for this term include Diarmaid MacCulloch, 'Henry VIII and the Reform of the Church', in MacCulloch (ed.), The Reign of Henry VIII (London, 1995), 168; Greg Walker, Persuasive Fictions: Faction, Faith and Political $\underline{\text { Culture in the Reign of Henry VIII (Aldershot, 1996), 136-7; Alec Ryrie, The Gospel }}$ and Henry VIII (Cambridge, 2003), xv-xvi. 
We might think therefore that the semantic handover from evangelical to Protestant should point to a significant historical shift taking place. Identifying the moment when English reformers assimilated and appropriated a word of foreign provenance and resonances would surely do much to elucidate the evolution of confessional identities in England, and the self-understandings of the Reformation movement in a national and international context. In recent years, one leading scholar, Diarmaid MacCulloch, has cautiously identified this moment, stating that "Protestant" as a usage did not become naturalized in England until the reign of Mary'. ${ }^{25}$ This chronology makes considerable sense. The vicissitudes of Mary's reign, particularly the re-imposition of papal obedience and the intense persecution of nonconformists, seem likely to have produced a hardening and clarifying of religious divisions, something which made clear team-labels a theological and sociological imperative. Catholics and Protestants could thenceforth confront each other across both a deepening doctrinal chasm, and an enclosed field of semantic discourse.

This essay, however, will suggest the need for a fundamental rethink of the character and timescale of the naming and labelling process. Attempts to anchor the settled form and usage of the word in the reign of Mary, far from being scrupulously cautious, may in fact be substantially premature. The self-consciously 'Protestant' character of the English Reformation was not an early, or even a mid-Tudor revelation, but a slow, reluctant and intensely contested matter of ascription, the unfolding story of which is exceptionally revealing of the dynamic processes of cultural identity.

${ }^{25}$ Diarmaid MacCulloch, Thomas Cranmer: A Life (New Haven and London, 1996), 2. Other historians have followed him in this: Patrick Collinson, 'Night Schools, Conventicles and Churches: Continuities and Discontinuities in Early Protestant Ecclesiology', in Marshall and Ryrie, Beginnings, 230-4; Peter Marshall, Reformation England 1480-1642 (London, 2003), 111; Judith M. Richards, Mary Tudor (Abingdon, 2008), 186. Alec Ryrie, The Age of Reformation: The Tudor and Stewart Realms 1485-1603 (Harlow, 2009), 93, suggests that we can start calling evangelicals Protestants 'around 1550'. That 'Protestants' were not to be found before the reign of Mary was in fact noted in 1939 by M. M. Knappen, Tudor Puritanism (Chicago, new edn., 1966), 487, though he felt that desisting from it for the earlier period 'would result in practices strange, if not largely unintelligible, to the modern reader.' 
At the start of the reign of Edward VI, the fervent gospeller Thomas Hancock became minister of Poole in Dorset. He later reminisced that it was a town whose inhabitants enthusiastically 'embraced God's word... [and] were the first that in that parte of England were called Protestantes. ${ }^{26}$ The phraseology is significant: were called, not called themselves. In mid-Tudor England, when it was not being used about foreigners, Protestant was almost invariably a derogatory nickname applied to their enemies by religious conservatives. Only in sarcastic judicial asides does the word appear in the transcript of Marian heresy trials. Bishop James Turberville of Exeter could not contain his exasperation with the sacramentarian Agnes Priest in 1558: 'I promise you, you are a iolly Protestant. I pray you in what scholes haue you bene brought vp? ${ }^{27}$ More sympathetic, if equally condescending, Stephen Gardiner's chancellor Thomas Martin ended his examination of John Careless in 1556 by remarking that 'thou art a pleasaunt fellow as euer I talked with of all the Protestants... I am sory that I must depart with thee so soone. ${ }^{28}$ The term does not seem to have been used with very much regularity by the regime's apologists, though Nicholas Harpsfield commended Thomas More's books for 'God's cause and religion... against the Protestantes', and Bishop Edmund Bonner castigated in passing the irritating habit among heretics of referring to 'the Lord' rather than 'Our Lord'. Such 'newe fangled wyttes' did so, he thought, only for 'singularitie, or for a glorious badge of a protestaunt'. ${ }^{29}$

An exception to the broad lack of facility with the term is to be found with the most effective and demotic of Marian propagandists, the London hosier, Miles Huggarde, whose The Displaying of the Protestantes of 1556 was the first English book to use the term in its title. 'Protestant' ricochets through Huggarde's text,

${ }^{26}$ John Gough Nichols (ed.), Narratives of the Days of the Reformation, Camden Soc., 77 (London, 1859), 77.

${ }^{27}$ John Foxe, Acts and Monuments (London, 1570), 2250.

${ }^{28}$ John Foxe, Acts and Monuments (London, 1576), 1814.

${ }^{29}$ Eamon Duffy, Fires of Faith: Catholic England under Mary Tudor (New Haven and London, 2009), 183; Edmund Bonner, A Profitable and Necessarye Doctrine (London, 1555, STC 3283.3), sig. D2v. There is, however, no use of 'Protestant' in such core Marian texts as John Christopherson's An Exhortation to all Menne to Take Hede and Beware of Rebellion (London, 1554, STC 5207), John Proctor's The Historie of Wyates Rebellion (London, 1554, STC 20407), or Thomas Watson's Twoo notable Sermons (London, 1554, STC 25115.3). 
sometimes in couplets such as 'Protestants and heretics', or in other memorable coinages like 'hedgecreping protestantes'. The work has ten separate index entries for the term, culminating in the lapidary pronouncement that 'The Protestants are bastards, ${ }^{30}$

Huggarde's introductory remarks reflected (revealingly) that 'peraduenture some man will muse of this woorde Protestante, because it is no usuall terme'. But it was, he claimed, 'a worde greatly pleasyng themselues, a woorde invented after theyr hartes desyre, a worde devysed of themselves, a woorde wherein they greatly triumphe'. ${ }^{31}$ Evidence that English reformers were already habitually using the term to describe themselves is, however, lacking. The Marian exile John Plough composed, in self-conscious rebuttal of Huggarde's book, An Apology for Protestants, though, frustratingly, no copy of this work has survived. ${ }^{32}$ MacCulloch has pointed to 'pioneering uses' of the word Protestant by the gospeller Edward Underhill in $1553 .{ }^{33}$ But Underhill's autobiographical narrative of his misadventures in that year was not written until the 1560s, and his only reported use of the term from Mary's reign itself is much more ambiguous: interrogated before the Council in August 1553 for composing an anti-papist ballad, Underhill was challenged as to what he actually meant by the term 'papist'. He replied guardedly that 'your honors do knowe that in this controversy thatt hathe byn sume be called papistes and sume protestaynes' ${ }^{34}$ Less apparently ambiguous is the deposition made by the Duke of Suffolk's secretary, Thomas Rampton, about treasonous plotting in the midlands at the time of Thomas Wyatt's rebellion in early 1554. Rampton confessed to a conversation with a local sympathiser, who praised the duke as one who stuck to God's truth, 'whereby I noted hym to be a protestant. ${ }^{, 35}$ But we have to remember that this was a confession in front of the Catholic authorities, whose preferred terms of reference might be expected to apply.

Reformers in Mary's reign regularly noted use of the term, but always in the context of mock and derision. John Bradford, in his Paraphrase of Psalm 78, reflected

\footnotetext{
${ }^{30}$ Miles Huggarde, The Displaying of the Protestantes (London, 1556, STC 13558), (among numerous other references) fos. 7v, 8r, 14v, 35v, 64r, 70v, 101v, 115v.

${ }^{31}$ Ibid., fo. 8r-v.

32 Brett Usher, 'Plough, John (d. 1562)', ODNB, Online Edition.

${ }^{33}$ MacCulloch, 'Henry VIII', 280n.

${ }^{34}$ Nichols, Narratives, 141-2, 148, 163.

${ }^{35}$ NA, SP $11 / 3$, fo. 54 r.
} 
ruefully how 'everywhere now it is tauntingly spoken, "where are our protestants? Where are these new gospellers?", 36 Thomas Becon similarly complained about the triumphalism of the Reformation's enemies: 'lyke hell houndes yell they out and saye: Beholde your Protestantes. Se your new Gospelers'. 37 'Odious' use of the terms 'protestauntes, papistes, Pharisees, or gospellers' was also remarked on by the imprisoned former bishop of London, Nicholas Ridley. Though his body was captive, Ridley intended freely to utter his mind on the matter of the Lord's Supper, under the protestation that he would never deviate from the sense of God's holy word: 'call me protestaunt who listeth'. ${ }^{38}$ But this punning, rhetorical, and polemical backhand return was as close to ownership of the expression as Marian reformers were prepared to come.

This started to change, though only a little, after the accession of Elizabeth. Among writers of the early 1560s, James Pilkington, bishop of Durham, and former exile in Germany and Switzerland, was distinctly unusual in seeming comfortable with the term as standard shorthand for his allies and attitudes. ${ }^{39}$ It does appear a few times in the 1563 edition of Foxe's Acts and Monuments, though interestingly never in association with the Marian martyrs themselves. There are a couple of references to the travails of 'protestants' in Henry VIII's reign, and Foxe characterised the 1559 conference on religion organized by the incoming Elizabethan regime as having 'the Bishops on the one side and the Protestants, that is, the late banished Preachers, on the other' ${ }^{40}$ In setting out to the queen why he could not minister in a chapel containing crucifix and candles, Bishop Richard Cox of Ely declared that it was a matter of fundamental division between papists and 'the protestants, as they term them'. ${ }^{41}$

\footnotetext{
${ }^{36}$ John Bradford, Works, ed. Aubrey Townsend (2 vols, Cambridge, 1848-53), i, 2834.

${ }^{37}$ Thomas Becon, A Comfortable Epistle, too Goddes Faythfull People in Englande (Strasburg, i.e. Wesel?, 1554, STC 1716), sig. B5r. Becon had earlier complained about the language of sectarian division, stemming from the devil: 'Ar not some called papists, some protestants, some Anabaptists, some sacramentaries?': A Fruitful Treatise of Fasting (London, 1551?, STC 1722), sigs. A4v-5r.

${ }^{38}$ Nicholas Ridley, A Brief Declaracion of the Lordes Supper (Emden, 1555, STC 21046), sigs. A6r, B3v.

${ }^{39}$ James Pilkington, Works, ed. James Scholefield (Cambridge, 1842), 541, 562, 583, $585,594,611$. For another favourable self-ascription from the early 1560 s, see J. S. Purvis (ed.), Tudor Parish Documents of the Diocese of York (Cambridge, 1948), 218.

${ }^{40}$ John Foxe, Acts and Monuments, (London, 1563), 513, 608, 685, 1739.

${ }^{41}$ John Strype, Annals of the Reformation, 4 vols. (Oxford, 1824), i. part. ii, 501.
} 
But through the first decade of Elizabeth's reign and beyond, textual sightings of 'Protestants' seem more likely to occur in Catholic sources than in reformed ones: the expression 'the religion of Protestants' may have been a sarcastic coinage of the exile Thomas Stapleton. ${ }^{42}$ There are understandable theological and polemical reasons for this imbalance. A case in point is the thunderous controversy initiated by John Jewel's famous 'Challenge Sermon' of 1559, and followed up in his subsequent Apology of the Church of England, and Defence of the Apology. That Jewel tended scrupulously to avoid using the word Protestant is hardly surprising: he aimed to prove his Church's doctrine to be of greater antiquity than Rome's, and concordant with the teaching of the early fathers. ${ }^{43}$ 'Protestant' was a word of datable modern origins, with connotations of novelty. For precisely these reasons, Jewel's Catholic opponents rarely lost an opportunity to call him a Protestant, or to link his 'protestanticall' doctrines to heresy, ancient and modern. ${ }^{44}$ The absurdity of Protestants appealing to antiquity was a particular obsession of the Jesuit John Rastell, whose numerous polemics in the 1560s frequently contrasted the authority of 'olde Catholikes' with that of 'newfangled Protestantes'. 45

${ }^{42}$ The History of the Church of Englande. Compiled by Venerable Bede, tr. Thomas Stapleton (Antwerp, 1565, STC 1778), fo. \|2r.

${ }^{43}$ Peter Milward, Religious Controversies of the Elizabethan Age (Lincoln, Neb., 1977), 1-5. Jewel's handful of references to Protestants are to Germans: A Defence of the Apologie of the Churche of Englande (London, 1567, STC 14600.5), 37, 211.

${ }^{44}$ For 'playing the right Protestant', 'protestanticall' and 'protestant like': Thomas Stapleton, A Returne of Untruthes upon M. Jewelles Replie (Antwerp, 1566, STC 23234), fos. 102r, 103r-v, 122v; Stapleton, A Counterblast to M. Hornes Vayne Blaste Against M. Fekenham (Louvain, 1567, STC 23231), fo. 19v. See also Thomas Dorman, A Proufe of Certeyne Articles in Religion (Antwerp, 1564, STC 7062), fo. $73 \mathrm{v}$; Lewis Evans, A Brieve Admonition unto the Nowe Made Ministers of Englande (Antwerp, 1565, STC 10589), sigs. A5r, B1v, B3v, B5v, B6r; John Leslie, A Treatise of Treasons Against Q. Elizabeth (Louvain, 1572, STC 7601), 'The Preface to the English Reader', fo. 96r.

${ }^{45}$ John Rastell, A Briefe Shew of the False Wares Packt Together in the Named, Apology of the Churche of England (Louvain, 1567, STC 20725), fo. 7v. See also Rastell, A Confutation of a Sermon, Pronou[n]ced by M. Iuell, (Antwerp, 1564, STC 20726), fos. 4v, 11v, 12r, 18v, 21r, 33v; Rastell, A Copie of a Challenge, Taken owt [sic] of the Confutation of M. Iuells Sermon (Antwerp, 1565, STC 20727), fos. 10r, 11r; Rastell, A Replie Against an Answer (falslie intitled) in Defence of the Truth (Antwerp, 1565, STC 20728), 'to the reader', fo. 4r; Rastell, The Third Booke, Declaring by Examples out of Auncient Councels, Fathers, and Later Writers, that it is Time to Beware of M. Iewel (Antwerp, 1566, STC 20728.5), fos. 23v, 58v, 74r; Rastell, A Treatise Intitled, Beware of M. Iewel (Antwerp, 1566, STC 20729), fos.1r, 101r, 152v. 
In the works of Rastell and other clerical exiles, the terms 'Protestant' and 'Catholic' are endlessly juxtaposed. Perhaps, as a consequence of familiarity, the pairing may seem to us conventional and unexceptional, but if so, we risk losing sight of the heavy ideological charge both words carried in the sixteenth century. Every time the Louvain-based exiles called themselves Catholics, they were making an assertive theological claim - they were not 'papists' but members of the true Catholic Church of the ancient creeds. 'Protestants', by contrast, were sectarians, schismatics, and heretics. To the Jesuit Robert Parsons, it seemed self-evidently absurd that 'the Protestantes doe saye them selues to be good Catholickes' ${ }^{46}$ For Nicholas Sander, the departure of Luther and his allies was no less than a separating of the wheat from the tares. 'For two bodies are made, one of Catholikes, an other of the Protestantes. And the Churche of God remaineth marvellously purged from that wicked generation' ${ }^{47}$ The divisive, splintering character of Protestantism was a recurrent theme. Luther was the 'father of all this blessed broode of protestants', and his spiritual progeny included 'the Anabaptistes, the Sacramentaries, and the Confessionistes, whiche are commonly called protestant preachers'. These were pernicious heretics, whether 'Lutherans, ghospellers, protestants, or howsoeuer they call them selues'. ${ }^{48}$ The preface to a 1567 work of Thomas Stapleton explained to its readers that 'of Protestantes, some be Lutherans, some Zwinglians, some Anabaptistes, some Trinitaries, and some be of other sectes', yet all 'at mutuall and mortall enemitie emonge themselues'. ${ }^{4}$

As it flowed from Catholic pens, 'Protestant' was thus both a casual insult, and a calculated theological put-down. The intended targets knew it. The civil lawyer Walter Haddon remarked in 1565 on the tendency of papist writers to find fault with the moving of the communion table, and thus 'cryeth out uppon thinconstancy of these protestantes'. ${ }^{50}$ The bishop of Lincoln, Thomas Cooper, imagined Catholics, particularly French ones, declaring in furious rage, 'Let us roote from the face of the

\footnotetext{
${ }^{46}$ Robert Parsons, A Brief Discours Contayning Certayne Reasons why Catholiques Refuse to goe to Church (Douai, i.e. East Ham, 1580, STC 19394), fo. 32r.

${ }^{47}$ Nicholas Sander, The Supper of Our Lord Set Foorth According to the Truth of the Gospell and Catholike Faith (Louvain, 1566, STC 21695), fo. 13v.

${ }^{48}$ The Apologie of Fridericus Staphylus Counseller to the Late Emperour Ferdinandus, tr. Thomas Stapleton (Antwerp, 1565, STC 23230), fos. 36r, 98r-v, 102r.

${ }^{49}$ Stapleton, Counterblast to M. Hornes Vayne Blaste, Preface to the Reader.

${ }^{50}$ Walter Haddon, A Sight of the Portugall Pearle, that is, the Aunswere of D. Haddon Maister of the Requests... against the Epistle of Hieronimus Osorius a Portugall (London, 1565, STC 12598), Preface.
} 
earth these Protestantes, these Hugonotes, these Hererikes.' Looking back to the persecutions of the early church, he reflected that 'the name of a Christyan in those dayes, was in that state, as nowe in some Countreyes, the name of a Protestante or Gospeller is. ${ }^{, 51}$ Numerous authors simply refused to accept their opponents' terms of reference. From the 1560s onwards there are frequent references in English polemical works to 'them whom ye call protestants', 'the Protestante or Gospeller (as you call vs)', 'Christians called heretikes, and in reproch Protestants', 'true Christians, whom you call the Protestants', and to papalists calling 'your selves Catholikes and us protestantes, yea heretikes at pleasure'. ${ }^{52}$ The Catholic biblical translator, Gregory Martin, in fact conceded that 'Protestant' was not a name his adversaries had willingly adopted. But there was an appropriate analogy with ancient heretical sects 'for so were the names of Arians and the rest of old, imposed by others, and not chosen commonly of themselves'. His suggestion that the Protestants seemed 'well content therewith' was an intentional provocation. ${ }^{53}$

We might expect theologians, attuned to the power and pitfalls of language, and locked in a war of words with papalist opponents, to be peculiarly sensitive and careful, and it is a moot point whether their diffidence about the embrace of the word 'Protestant' was representative of mid-Elizabethan public culture as a whole. In so far as the governmental record is concerned, it is interesting that the great majority of instances of the words 'Protestant' and 'Protestants' in the calendars of the

\footnotetext{
${ }^{51}$ Thomas Cooper, Certaine Sermons Wherin is Contained the Defense of the Gospell Nowe Preached (London, 1580, STC 5685), 181, 219.

52 James Calfhill, An Answer to John Martiall's Treatise of the Cross, ed. Richard Gibbings (Cambridge, 1846), 5, 134-5; John Bridges, The Supremacie of Christian Princes (London, 1573, STC 3737), 909; William Fulke, Two Treatises Written $\underline{\text { Against the Papistes (London, 1577, STC 11458), 66; Fulke, A Briefe Confutation, of }}$ a Popish Discourse (London, 1583, STC 11421), fo. 19r; Perceval Wiburn, A Checke or Reproofe of M. Howlets Untimely Shreeching (London, 1581, STC 25586), fo. 85r (also fos. 15r, 15v, 58r). See also William Charke, A Treatise Against the Defense of the Censure (Cambridge 1586, STC 5009), 109; Richard Bancroft, $\underline{\text { A Sermon }}$ Preached at Paules Crosse (London, 1588, STC 1347), 3. ${ }^{53}$ Gregory Martin, The New Testament of Iesus Christ (Rheims, 1582, STC 2884), 323.
} 
Elizabethan state papers concern foreign policy, and the doings of Frenchmen, Germans and Scots. ${ }^{54}$ The exotic associations of the term, so palpable in the time of Henry VIII, continued to resonate in the reign of his daughter. ${ }^{55}$ But Elizabethan England's alignment in the confessional and ideological conflicts of western Europe may have started to give the term more local traction, as for example, in William Cecil's paper of 1569, proposing a defensive alliance of England 'with all Princes Protestants'. 56 The prospect of Elizabeth's marriage to the Catholic duke of Anjou at the end of the 1570s may also have helped focus a sense of semantic as well as ideological connection with those of the duke's countrymen who were not his coreligionists. The dissident pamphleteer John Stubbes argued that 'the very name of the Parisien mariage should a fray any protestant of Eugland or Fraunce from euer loking for any good to come' of it, while closer to the centres of power, Burghley himself included in a set of notes on perils attending the match 'Protestants touch'd - Papists exalted. ${ }^{57}$ But it is far from clear that 'Protestant' had become a workaday word of domestic policy, at least during Elizabeth's first two decades.

Its wider cultural diffusion at this time is more difficult to gauge. From the early 1570s one finds it being used across a range of different types of printed texts, though less frequently than might have been expected. ${ }^{58}$ There is a noticeably freer

\footnotetext{
${ }^{54}$ This is true of just over three-quarters of summaries in the online calendars where the words 'Protestant' or 'Protestants' appear, though one has to allow here for the vagaries of $19^{\text {th }}$-century editing.

${ }^{55}$ Ironically, it was not a term in this period much favoured by members of the continental churches to describe themselves: Siegfried Bräuer, 'Protestantism: History of the Term', in Hans J. Hillerbrand (ed.), The Oxford Encyclopedia of the Reformation (4 vols, Oxford, 1996), iii, 357-8.

${ }^{56}$ Samuel Haynes (ed.), A Collection of State Papers... left by William Cecill Lord Burghley, vol. 1 1542-1570 (London, 1740), no. 607.

${ }^{57}$ John Stubbes, The Discouerie of a Gaping Gulf (London, 1579, STC 23400),sig. B5r; William Murdin (ed.), A Collection of State papers... left by William Cecil Lord Burghley: Vol. 2 1571-1596 (London, 1759), no. 238. See also no. 243, a proposal from January 1579 that to avoid the perils of foreign wars, Elizabeth should pluck down the strength and government of English papists 'and delyver all the strength and government of your realm into the hands of wise, assured, and trusty Protestants'.

${ }^{58}$ For example, Roger Ascham, The Scholemaster (London, 1570, STC 832), fo. 54v; Acham, A Report and Discourse Written by Roger Ascham, of the Affaires and State of Germany (London, 1570, STC 830), a work unusual in its extensive use of the term; Thomas Knell, An Answer to a Papisticall Byll, Cast in the Streetes of Northampton (London, 1570, STC 15030): a single sheet broadside, which alternates in verse dialogue the claims of 'The Papist' and 'The Protestant'; Thomas Norton, An Addition Declaratorie (London, 1570, STC 18679a), sig. B1v; Norton, A Disclosing
} 
use of the term specifically to describe Englishmen in John Foxe's second, 1570, edition of the Acts and Monuments than in the first, especially in marginal glosses. ${ }^{59}$ An extensive survey of private correspondence would doubtless reveal more about the circulation of the term at this time. Yet the calendars and extracts provided by Access to Archives, admittedly an extremely crude diagnostic test, contain only a single Elizabethan example: a wry reference in a 1578 letter of Sir Henry Neville to a recent visitation of Exeter College, Oxford, 'and never a Protestant found in it' ${ }^{60}$ There is also a surprising dearth of 'Protestants' in Elizabethan memorial culture. It is true that the elegist George Whetstone included in his published tribute to Sir Nicholas Bacon the information that 'He was in religion a good protestant', and wrote similarly of the earl of Bedford that 'He was alwayes a most godly Protestant' ${ }^{61}$ But only rarely does the word seem to have found its way in the sixteenth century onto monuments, and into epitaphs, elegies and funeral sermons. ${ }^{62}$

The apparent paucity of the word in printed sources, and in elite cultural media, does not necessarily mean that ordinary people were not routinely using it, in their homes, on the streets, and in the alehouse. ${ }^{63}$ One possibility is that the word was increasingly common social currency, but that it was imbued with a vulgar, demotic character that made the educated hesitant fully to embrace it. There is support for this

of the Great Bull (London, 1570, STC 18679), sigs. B1r, B4r; Bridges, Supremacie of Christian Princes, 100, 588, 909; Urbanus Rhegius, A Necessary Instruction of Christian Faith, tr. John Foxe (London, 1579, STC 20848), 'Preface', marg. note: 'Difference between the Papist and the Protestant'.

${ }^{59}$ Foxe, Acts and Monuments (1570), 13, 1692, 1582, 1703, 1773, 1853, 2125, 2300. Unlike in 1563, Foxe does occasionally refer to victims of the Marian regime as 'godly Protestants': 2134, 2113, 2125. Interestingly, however (p. 1413), he includes Protestant among the 'termes of variance and dissension' that Henry VIII condemned in his 1545 address to parliament, albeit it is not found in any contemporary account of the speech: see Peter Marshall Religious Identities in Henry VIII's England (Aldershot, 2006), 157-65.

${ }^{60}$ Longleat House, Correspondence of Sir John Thynne, TH/VOL/IV/1, fol. 184.

${ }^{61}$ George Whetstone, A Remembraunce, of the Woorthie and Well Imployed Life, of the Right Honorable Sir Nicholas Bacon Knight (London, 1579, STC 25343), sig. B2v; Whetstone, A Mirror of Treue Honour and Christian Nobilitie Exposing: the Life, Death, and Divine Vertues, of the Most Noble, and Godly Lorde Frauncis Earle of Bedford (London, 1585, STC 25342), sig. C3r.

${ }^{62}$ See Peter Marshall, Beliefs and the Dead in Reformation England (Oxford, 2002).

${ }^{63}$ Testing this would require a thorough survey of court depositional and other archival material, such as has not been possible to undertake for this essay. The word does not, however, feature much if at all in the examples of popular speech collected by Haigh, Plain Man's Pathways, or by David Cressy, Dangerous Talk: Scandalous, Seditious and Treasonable Speech in Pre-Modern England (Oxford, 2010). 
hypothesis in the fact that, in what we now think of as Protestant texts, a strikingly high proportion of occurrences, from the 1550s through to the $1580 \mathrm{~s}$, occur in a context which is not celebratory, but distinctly censorious: the condemnation of hypocrisy, Nicodemism, and mere 'carnal' gospelling - the outward motions of true religion, combined with imperviousness to its transformative message. ${ }^{64}$ Thus the only Protestants to appear in John Bradford's treatise on The Hurt of Hearing Mass are 'popish protestants, mass-gospelers'. Bradford's farewell address to the people of Lancashire and Cheshire suggested that God's wrath had fallen on them for having 'played the wanton gospellers, the proud protestants, hypocritical and false Christians'. 65 'Vayn, iangling \& counterfeit protestants' were condemned in a 1571 Paul's Cross sermon of John Bridges, while James Bisse chastised those 'that beare the name of Protestantes' from the same pulpit in $1581 .{ }^{66}$ John Woolton warned against the hypocrisy of 'lip-gospellers and protestants' in his Christian Manual of 1576, and Leonard Wright fulminated against 'dissembling Protestants' in his Summons for Sleepers of $1589 .{ }^{67}$

Such counterfeiters might be cynical conformists, like those identified in a sermon of Edwin Sandys: 'when popery hath the upper hand, then a papist; when the gospel is in due estimation, a protestant'. Lancashire, thought William Harrison, thronged with 'Church Papists, prophane Atheists, and carnall Protestants'. ${ }^{68}$ Or they might be clergymen who, according to John Northbrooke, thought that because they observed the order of service, wore a square cap, a cope and a surplice, 'none can saie

${ }^{64}$ On this theme, see Patrick Collinson, The Religion of Protestants: The Church in English Society 1559-1625 (Oxford, 1982), ch. 5; Alexandra Walsham, Church Papists: Catholicism, Conformity and Confessional Polemic in Early Modern England (Woodbridge, 1993), ch. 5; Alec Ryrie, 'Counting Sheep, Counting Shepherds: the Problem of Allegiance in the English Reformation', in Marshall and Ryrie, Beginnings.

${ }^{65}$ Bradford, Works, ii, 327, 330, 331; i, 390, 452.

${ }^{66}$ John Bridges, A Sermon, Preached at Paules Crosse on the Monday in Whitson Weeke (London, 1571, STC 3736), 35; Walsham, Church Papists, 106.

${ }^{67}$ John Woolton, The Christian Manual (Cambridge, 1851), 23; Leonard Wright, $\underline{A}$ Summons for Sleepers Wherein Most Grieuous and Notorious Offenders are Cited to Bring Forth True Frutes of Repentance (London, 1589, STC 26034.3), 26, 28.

${ }^{68}$ Edwin Sandys, Sermons, ed. John Ayre (Cambridge, 1851), 183; Walsham, Church Papists, 113. See also Ambrosius_Autpertus, A Monomachie of Motives in the Mind

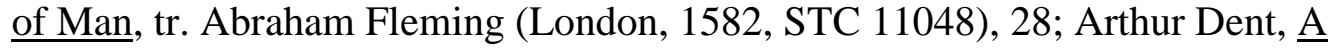
Sermon of Repentaunce (London, 1582, STC 6649.7),sig. B7v. 
blacke is their eyes, but that they are good protestantes' ${ }^{69}$ Alternatively, they might be people whose external profession of doctrine was simply not matched by any inner experience of conversion or grace. Edward Dering considered it worth little to 'use thy libertie, say thou art a Protestant, renounce the Pope, except thou love righteousnesse'. ${ }^{70}$ Particularly heartfelt was John Norden's monition that it was not 'the title of a Protestant (wherof some doe boast)' that made a man into a true Christian; those who believed 'the bare name of a protestant' would be enough to acquit them in the last day were sorely deceived. ${ }^{71}$ To the preacher John Bate, such people were 'double faced protestants', and John Udall considered it scandalous that he lived in times when every man might 'put on the name of a protestant', and manage to be 'taken of others, to be of a true and sound religion: yea though his life and conversation doe sweare the contrarye'. ${ }^{72}$ The stolidity of such hypocrites was all too easily satirised. The carnal Autophilus in a dialogue of Bate's swears that he is no papist, and when the 'good Christian' Philoxenus snaps back, 'No, nor no protestant neither', Autophilus retorts, 'You might as well call mee no good subiect'. In a dialogue of Udall's on the state of the Church of England, the character of Demetrius, a usurer, has an uncomplicated view of what constitutes true religion: 'Yea by $\underline{S}$. Mary, I am a protestant, for I loue to eate flesh on the Friday' ${ }^{73}$ It was, observed Sir John Harrington towards the end of Elizabeth's reign, beyond doubt that 'all the careless and indifferent sorte, and all the simple and ignorant present themselves under that name'. ${ }^{74}$ The long-running topos of the 'carnal protestant' thus seems to indicate on the part of some theologians and preachers a distinct unease about the

\footnotetext{
${ }^{69}$ John Northbrooke, Spiritus est Vicarius Christi in Terra (London, 1571, STC 18663), sig. A3r.

${ }^{70}$ Edward Dering, XXVII. Lectures, or Readings, Upon Part of the Epistle Written to the Hebrues (London, 1577, STC 6727),_68.

${ }^{71}$ John Norden, A Mirror for the Multitude... with a Necessary Conclusion, that it is not the Name, or Title of a Protestant, Christian, or Catholicke, but the True Imitation of Christ, that Maketh a Christian (London, 1586, STC 18613), 91, 95, 98, 106.

${ }^{72}$ John Bate, The Portraiture of Hypocrisie (London, 1589, STC 1579), 'To the Christian Reader', 35-6; John Udall, Amendment of Life Three Sermons (London, 1584, STC 24489), sig. E5r. See also George Gifford, A Dialogue Between a Papist and a Protestant Applied to the Capacitie of the Unlearned (London, 1582, STC 11849), fos. 2r, 39r-v; Stubbes, Gaping Gulf, sig. A8r-v.

${ }^{73}$ Bate, Portraiture of Hypocrisie, 86; John Udall, The State of the Church of Englande Laide Open in a Conference (London, 1588, STC 24506), sig. C4v. ${ }_{74}$ John Harrington, A Tract on the Succession to the Crown (A.D. 1602), ed. Clements R. Markham (London, 1880), 5.
} 
people's complacent and unreflective adoption of an insufficiently challenging badge of spiritual identity. ${ }^{75}$

If ordinary parishioners were (sometimes misguidedly) proud to call themselves Protestant, it took the world of authorship and publishing some time to catch up. Remarkably, it is not until the 1580s that the word Protestant appears in the titles of any surviving books other than those of Catholics opposed to the Reformation. ${ }^{76}$ The first of these was the Essex vicar George Gifford's 1582 Dialogue Between a Papist and a Protestant Applied to the Capacitie of the Unlearned (STC 11849). A short pamphlet appearing during the Armada crisis of 1588 billed itself $\underline{\text { An }}$ Oration Militarie to all Naturall Englishmen, Whether Protestants, or Otherwise in Religion Affected, to Move Resolution in these Dangerous Times (STC 18836.5). There followed in 1592 an anonymous address To the Seminarye Priests Lately Come Over... Who are not to be Believed Against any Unlearned Protestant (STC 22185). It is notable that all these works were directed towards a demotic popular audience.

Even in the 1580s, respectable theologians remained wary of nailing their colours too firmly to the Protestant mast. Robert Crowley, in a work attacking Jean d'Albin de Valsergues' Notable Discourse... with an offer made by a Catholike to be a Learned Protestant, defiantly accepted the challenge to argue the author over to the side occupied by 'we protestants', declaring himself on the opening page 'a Protestant christian'. ${ }^{77}$ But Crowley nonetheless made reference to his opponent's abuse of those 'whom he calleth protestants', and he self-consciously littered his text with polemical references to 'our Protestant Catholique church' and to the 'Protestant Catholikes' of his own and the preceding generation; true Catholics in contradistinction to popish

\footnotetext{
${ }^{75}$ A contemporary analogy might be the way that some leaders of the Church of Jesus Christ of Latter Day Saints in Utah have come to dislike the designation 'Mormon' as having a merely communal or 'ethnic' connotation, and prefer the appellation LDS as a marker of personal commitment - an insight I owe to conversations during a visit to Salt Lake City in 2006.

${ }^{76}$ Two texts from the later 1570 s do not really undermine this statement: William Fulke's Two Treatises... one being an Answere of the Christian Protestant to the Proud Challenge of a Popish Catholike (1577) is echoing the title of a Catholic opponent; George Gilpin's 1579 translation of a famous work by Philip van Marnix, meanwhile, underlines a foreign provenance: The Bee Hive of the Romishe Churche: Wherein the Author a Zealous Protestant, Under the Person of a Superstitious Papist doth... Driely Refell the Gros Opinions of Popery (London, 1579, STC 17445.5). ${ }^{77}$ Robert Crowley, A Deliberat Answere Made to a Rash Offer (London, 1588, STC 6084), fos.1r, 44v, 80r, 85r.
} 
schismatics. ${ }^{78}$ William Fulke, refuting the same text, conceded that 'we do sometimes use these names: Congregation, and Gospellers or Protestantes'. The latter, he pedantically recounted, 'came first of them that made protestation against the decree of Spires in Germanie, and from that time hath bene attributed to the professors of the Gospel'. But it was a name they 'doe not so much delight in, as you doe in the name of papistes' ${ }^{79}$ In a subsequent work, Fulke made a point of refusing to rise to the bait of being taunted as a Protestant: the word, 'if any doe use', was a historical accident devoid of any real significance. If pressed,

that we make not dangerous, to acknowledge the name of Protestants, I confesse, $\mathrm{y}^{\mathrm{t}}$ when nothing is understod by that name, but men which professe that true doctrine which we doe, we greatly strive not for the name. $\underline{S}$. Paul him selfe openly acknowledged $\mathrm{y}^{\mathrm{t}}$ he was a Pharise, when nothing was understood by the name but one that beleeued the resurrection of the dead. ${ }^{80}$

This analogy with the Pharisees was hardly a ringing endorsement, or suggestive of much emotional investment in the designation. With the exception of a lone example in a late work by Roger Ascham, I have not found any textual references to the incorporative formulae 'we Protestants' / 'us Protestants' before the early 1580s, and these expressions do not seem to have flowed smoothly from Protestant pens until after $1600 .^{81}$ In fact, it was not until the very end of the sixteenth century that the word Protestant had become respectable enough to stand unashamed and without ironic inflection in the titles of works of divinity, such as Andrew Willet's A Christian Letter of Certain English Protestants of 1599 (STC 13721) or William Barlow's $\underline{A}$ Defence of the Articles of the Protestants Religion of 1601 (STC 1449). Yet even at the height of what historians have dubbed an age of 'confessionalization', a self-

\footnotetext{
${ }^{78}$ Ibid, fos. 10r, 35v, 43r, 73r, 74r.

${ }^{79}$ Fulke, Two Treatises, 64-5, 67.

${ }^{80}$ William Fulke, A Retentive, to Stay Good Christians (London, 1580, STC 11449), 11, 13-14.

${ }^{81}$ Ascham, Scholemaster, fo. 54v; Wiburn, Reproofe, fo. 115v. Other examples include Philip Stubbes, A Motive to Good Workes (London, 1593, STC 23397), 73; Thomas Nashe, The Unfortunate Traveller (London, 1594, STC 18380), sig. K2r; William Vaughan, The Golden-Grove Moralized in Three Books (London, 1600, STC 24610), sigs. E2v, E8r; William Perkins, A Commentarie or Exposition, Upon the Five First Chapters of the Epistle to the Galatians (Cambridge, 1604, STC 19680), 75, 312; William Leigh, The Christians Watch (London, 1605, STC 15422), sig. D3v.
} 
conscious refusal of modern labels remained the public stance of many English reformers. ${ }^{82}$ The Cambridge divine, William Perkins, insisted that 'professours of the Gospell' should not receive the names of 'such as have been famous instruments in the church, as to be called Calvinists, Lutherans, etc'. Rather, they should glory in the title given to the disciples at Antioch, 'not by the devise of man, but by divine oracle': the 'name of Christian' ${ }^{83}$ In the course of his 1581 Tower debate with the Jesuit Edmund Campion, John Walker indignantly exclaimed that 'I am neither a Lutheran, a Calvinist, a Bezian, nor Zwinglian. I am only a man of God and a free Christian of Christ. ${ }^{84}$ The assigning of such nomenclature was a propaganda trick of the papists, a point underlined in a Jacobean sermon by the godly Oxford theologian, Henry Airay: 'if we be named after any other name then only the name of Christ Jesus, it is through their malice, not by our desire. ${ }^{85}$ The anti-papal polemicist Gabriel Powell rejected the label Protestant in 1604 as 'a name given to certain Germaines, that protested against... matters certes, that touch us nothing', while Matthew Sutcliffe a few years later shrugged off 'the ignominious name of Protestant put upon Catholike Christians by Antichrists abetters'. ${ }^{86}$ George Abbot admonished papists to remember that 'we challendge no name but Christians', while conceding that 'we do in writing \& speaking promiscuously use the word Protestants, as we do Religiosi, or Reformata Religionis homines, or Evangelici, ${ }^{87}$ William Fulke was similarly unenthused to be called a Protestant, 'though it be not so odious as to be called of any man' (i.e. to be termed a Calvinist or Lutheran). Rejecting all the 'nicke names, that it pleaseth you of

\footnotetext{
${ }^{82}$ See John M. Headley, Hans J. Hillerbrand and Anthony J. Papadas (eds.), Confessionalization in Europe, 1555-1700 (Aldershot, 2004).

${ }^{83}$ Cited in Charles H. and Katherine George, The Protestant Mind of the English Reformation (Princeton, 1961), 445. The allusion is to Acts 11:26.

${ }^{84}$ James V. Holleran (ed.), A Jesuit Challenge: Edmund Campion's Debates in the Tower of London in 1581 (New York, 1999), 144-5.

${ }_{85}$ Cited in George and George, Protestant Mind, 377.

86 Anthony Milton, Catholic and Reformed: The Roman and Protestant Churches in English Protestant Thought, 1600-1640 (Cambridge, 1995), 378-9, noting that a squeamishness about 'Protestant' may have been linked to the desire of some Jacobean divines to align themselves with the Eastern Churches in common 'Catholic' witness against Rome.

${ }^{87}$ George Abbot, The Reasons which Doctour Hill hath Brought, for the Upholding of Papistry (London, 1604, STC 37), 80-1.
} 
your charity to bestow upon us', he protested 'once for all, that we acknowledge none other name of our profession, but Christians, and Catholikes. ${ }^{, 88}$

This last retort contained an echo of a famous obiter dictum of the fourth century Latin father, Pacianus: 'Christian is my name; Catholic is my surname', a self-definition regularly rehearsed by reformed English writers of various complexions. ${ }^{89}$ As subscribers to the ancient creeds, 'Protestants' were professedly Catholic, and they formally denied their opponents any legitimate share in the ancient title. ${ }^{90}$ Indeed, from the reign of Henry VIII onwards, the derisory designation of 'papist' had been usefully employed to deprive Rome's adherents of any claim to Catholicity. ${ }^{91}$ Wearing, as it were, their theological Sunday best, Elizabethan and early Stuart divines continued to assert their Church's Catholic character. Thus Thomas Rogers's apologetic of 1585 was titled The English Creede Consenting with the True Auncient Catholique, and Apostolique Church, while William Perkins's 1597 work of controversy described the faith of A Reformed Catholike. ${ }^{92}$ The future archbishop of Canterbury, George Abbot, published in 1604 a treatise attacking The Upholding of Papistry, which is Falselie Termed the Catholike Religion. ${ }^{93}$ Catechisms expounding the ninth article of the Apostles' Creed - belief in 'the holy catholic

\footnotetext{
${ }^{88}$ William Fulke, A Confutation of the Rhemish Testament (New York, 1834), 155; Fulke, A Defense of the Sincere and True Translations of the Holie Scriptures (London, 1583, STTC 11430.5), 17.

${ }^{89}$ Harrington, Tract on the Succession, 108; Robert Abbot, The True Ancient Roman Catholike (London, 1611, STC 54), 45; Christopher Potter, Want of Charitie Iustly Charged on all Such Romanists, as Dare... affirme that Protestancie Destroyeth Salvation (Oxford, 1633, STC 20135), 82-3. See also Milton, Catholic and Reformed, 407-8.

${ }^{90}$ For example, Fulke, Confutation of the Rhemish Testament, 155-6.

${ }^{91}$ Marshall, 'Is the Pope Catholic?', 22-48;_Clancy, 'Papist-Protestant-Puritan', 22832.

92 Thomas Rogers, The English Creede Consenting with the True Auncient Catholique, and Apostolique Church (London, 1585, STC 21226.5); William Perkins, A Reformed Catholike, or, A Declaration Shewing How Neere We May Come to the Present Church of Rome in Sundrie Points of Religion (London, 1597, STC 19735.8). Robert Abbot's The True ancient Roman Catholike... Wherein the name of Catholikes is vindicated from Popish Abuse was one of a number of works Abbot wrote in defence of Perkins's Reformed Catholike against (Roman) Catholic attacks. ${ }^{93}$ Abbot, Reasons Which Doctour Hill hath brought. See also Matthew Sutcliffe (?), The Supplication of Certaine Masse-Priests Falsely Called Catholikes (London, 1604, STC 14430).
} 
church' - also sometimes took care to distinguish that universal entity from the particular church, or anti-church, of Rome. ${ }^{94}$

But only in the most theologically-correct of contexts did Catholic really remain an ambiguous or fiercely contested word as the sixteenth-century ran its course. Church of England apologists continued, for form's sake, to claim not to recognise papists as Catholics, while Romanist authors vociferously asserted their right to sole copyright of the word. The contest was never formally conceded, but in practice the balance swung heavily in the direction of Rome. As Thomas Clancy noted, 'there is plenty of evidence that even non-Papists used the term in off-guard moments to designate the Romanists'. Early in the seventeenth century, Burghley's protégé, the historian John Clapham, could write about papists, or 'the Catholics commonly so termed', a widespread usage complained about by James I in a speech to parliament of $1604 .{ }^{95}$ In an account of his spiritual odyssey, the Jacobean Church of England deacon, Catholic convert, and later Jesuit, Francis Walsingham, remembered a meeting with 'a certain old man of the Roman religion'. Walsingham informed the man of his intention to resolve the doubts in his mind by continuing to read books 'both on the Protestant and Papist sides'. But his interlocutor interrupted, suggesting that 'papist' was an inappropriate word with which to continue their dialogue, 'being a device only of such as... would make the word papist odious'. He was prepared to 'grant to you and yours the new particular name of Protestant, which yourselves chose at the Diet of Augustana'. But as for his own side, 'let us remain with our old general name of Catholic'. Walsingham readily conceded, 'both names being now well known'. ${ }^{96}$ The Jesuit Lawrence Anderton could later gloatingly recite a litany of Elizabethan and Jacobean luminaries - John Foxe, Andrew Willet, Lawrence Humphrey, Henry Jacob - who had all referenced their opponents simply as Catholics. $^{97}$

Some late Elizabethan controversialists, with a range of emphases from the sneering to the quasi-courteous, labelled their adversaries 'Romish Catholics', or

\footnotetext{
94 Ian Green, The Christian's ABC: Catechisms and Catechizing in England c. 15301740 (Oxford, 1996), 332-3.

${ }_{95}$ Clancy, 'Papist-Protestant-Puritan', 232, with several further $17^{\text {th }}$ century examples.

${ }^{96}$ Henry Foley (ed.), Records of the English Province of the Society of Jesus (London, 7 vols, 1877-1883), ii, 373.

${ }^{97}$ Lawrence Anderton, The Progenie of Catholicks and Protestants (Rouen, 1633, STC 579), bk. 4, p. 9.
} 
'Roman Catholics'. The expression was useful when an alternative was preferable to the openly contemptuous 'papist', as during the Spanish marriage negotiations in James I's reign. Papalists were often uncomfortable with the term, for it implied that, as the Jesuit scholar Herbert Thurston once put it, 'the Roman Church is only a species of the genus Catholic'. ${ }^{98}$ Yet in the seventeenth century they increasingly applied the expression to themselves. ${ }^{99}$ No-one in late Elizabethan or Jacobean England, however, hearing passing reference to a 'Catholic', could have supposed that what was meant thereby was an ordinary, loyal and communicant member of the Church of England.

If conforming members of the Church of England could not for practical and day-today purposes continue to be called Catholics, this leaves the key question of when it was that they began routinely to become Protestants, and why. There was of course no seminal moment of implementation, no edict of adoption. On balance, however, the evidence seems to point to the $1580 \mathrm{~s}$ as a transitional period when the word became more or less fully naturalised in an English context, and acceptable across a range of social classes and literary genres. In other words, it happened around the time historians now believe England was finally becoming a Protestant country on the ground and in a meaningful cultural sense. ${ }^{100}$ Despite continuing caveats, religious texts from the early 1580 s onwards are much more likely to use the word in a simply descriptive way. ${ }^{101}$ There is a revealing shift of tack in a 1583 polemic by the Catholic

\footnotetext{
98 Thurston, 'Name "Roman Catholic", 294-7, 299 (quote), 300.

${ }^{99}$ Clancy, 'Papist-Protestant-Puritan', 231-2. Robert Abbot suggested that with the appellation, papists were 'disclaiming thereby the communion and fellowship of the Catholike Church, and binding themselves in a partiall and factious confederacy': True Ancient Roman Catholike, 45.

${ }^{100}$ Diarmaid MacCulloch, The Later Reformation in England, 1547-1603 $\left(2^{\text {nd }} \mathrm{ed}\right.$., Basingstoke, 2001), 95-101, 113-19; Marshall, Reformation England, 150.

${ }^{101}$ Qualitative impressions on this are underlined in rough and ready fashion by the fully searchable volumes in EEBO, the number of which per decade containing the word 'Protestant' (including variant spellings and discounting Catholic sources) is: 1560s: 24 (6.7\% of the available text-searchable volumes); 1570s: 49 (11.3\%); 1580s: $96(17.8 \%)$. This does, of course, represent only a random sample of texts, albeit a large one (1334 volumes).
} 
exile, William Rainolds, who claimed to have observed how the word had become 'magnified in bookes, pulpits, and ordinarie phrase of talke'. John Foxe 'in his huge volume of Actes and Monumentes alwayes useth [it] as most proper to their gospel, \&

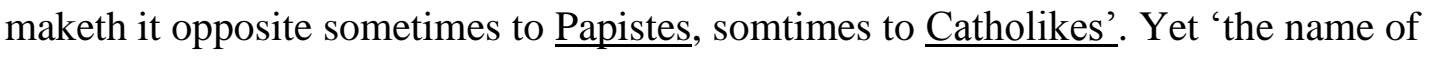
Protestantes, which commonly they usurpe, is wrongfully chalenged of them': it belonged properly to the German Lutherans who had protested against the decrees of the emperor. English heretics were more accurately termed Zwinglians, in recognition of 'their maister, ringleader, and apostle'. ${ }^{102}$ Having for decades dangled the term in their faces, the fact that a Catholic writer was arguing that reformers had no right to call themselves Protestants might suggest they were at last becoming comfortable in doing so.

From the turn of the seventeenth century, English Catholic polemic increasingly regarded the word 'Protestant', not as a handful of mud for flinging, but as a coin to be prized from their opponents' grasp. After the anti-papist polemicist John White declared in a work of 1608 that his aim was to 'help the seduced out of their errors and confirm Protestants in the truth', the Jesuit John Fisher challenged him to tell the world 'wherein consisteth the essence, or definition of a Protestant?' Fisher proceeded syllogistically to deconstruct the title's claim to substance or coherence. It could not mean only those holding Luther's doctrine, since that would exclude Wyclif and Hus, as well as White himself 'and his English sacramentary congregation'. If it embraced all believers in justification by faith, Waldo, Wyclif and Hus still failed to qualify. But if the only bond uniting disparate sects of 'evangelicall brethren' was to 'hold tooth and nayle against the pope', then not only were Wyclif and Hus good Protestants, 'but Iewes and Turks also'. ${ }^{103}$ The logic of this line of attack was followed to its conclusion in a work by another early Stuart Jesuit, Lawrence Anderton's The Non-entity of Protestancy. The argument here was that since 'Protestant' was 'a word only of distinction', dreamt up in the infancy of the

\footnotetext{
${ }^{102}$ William Rainolds, A Refutation of Sundry Reprehensions (Paris, 1583, STC 20632), 87-90.

${ }^{103}$ Timothy Wadkins, 'White, John (1570-1615)', ODNB; John Percy [John Fisher], A Reply Made unto Mr. Anthony Wotton and Mr. Iohn White (Saint-Omer, 1612, STC 10914), 304-5.
} 
movement to differentiate its adherents from the Catholics, it signified a concept devoid of all positive content. ${ }^{104}$

Within England meanwhile, controversial authors were in the last decades of the sixteenth century no longer so likely to disavow the term, or to hedge it about with adjectival qualifiers. In Andrew Willet's massive anti-Catholic compendium of 1592, the Synopsis Papismi, the point-by-point theses and refutations are headed, 'the papists' and 'the Protestants'. Willet was aware that these were both in their historic application terms of dissension and disapprobation, yet he regarded them as appropriate, indeed heuristic, and 'the name of Protestants we refuse not'. The papists, he hoped, would 'take no offence or grief hereby so to be called'; indeed, they could hardly do so since their entire faith and religion 'are pinned upon the Popes sleeue'. A Protestant, by contrast, was one

that professeth the Gospell of Iesus Christ, and hath renounced the iurisdiction of the sea of Rome, and the forced and unnaturall obedience to the Pope. These names therefore as best fitting both our professions, seeing no cause to the contrary, I purpose euery where to use and retaine throughout this Treatise. $^{105}$

'Protestant' may thus simply have hung around long enough for the inhibitions to relax, and for the familiarity to become irresistible: a triumph of linguistic attrition. Yet other developments in the second half of Elizabeth's reign most likely facilitated the transition. Willet frankly admitted valuing the term for its intrinsic taxonomic value, as a means of labelling and separating. The Cambridge Professor of Divinity, William Whitaker, suggested in 1585 that, 'being not a name of schism or sect', Protestant might as well be used as the name Catholic. More revealingly, he added that 'for distinction sake onely, being begon first at the diet of

${ }^{104}$ Lawrence Anderton, The Non-Entity of Protestancy (Saint-Omer, 1633, STC 577), $8,80,82$, and passim.

${ }^{105}$ Andrew Willet, Synopsis Papismi, that is, A Generall Viewe of Papistry (London, 1592, STC 29656), B2r. For a similar juxtaposition, see Thomas Lupton, The Christian against the Iesuite (London, 1582, STC 16946), which uses the term Protestant unselfconsciously throughout. 
Argsburgh, we are enforced to use it. ${ }^{106}$ Although an imperfect label, George Abbot told a Catholic opponent, he was prepared to be called a Protestant 'for difference sake from you'. 107

The imperative to mark difference was arguably increasing from the midElizabethan years: the rise in recusant numbers revealed that Catholicism was not about to fade away of its own accord, making it crucial for opponents and supporters of the regime to be identified and counted. When, in 1564, the bishops reported to the Privy Council on the opinions and reliability of the JPs in their dioceses, none of them used the word Protestant. Magistrates were 'favourers of true religion', or 'mislikers' of it, 'indifferent in religion', and occasionally 'papists'. ${ }^{108}$ Yet a set of proposals sent to Cecil in 1572 for an armed league in defence of the gospel pronounced that in its present state England was divided into three parties, 'the papyste, the atheyste and the protestant'. ${ }^{109}$ In the same year a government list of the principal gentleman in the East, North and West Ridings of Yorkshire placed symbols against each name, with a key denoting whether they were of 'the worste sorte', 'meane or lesse evyll', 'doubtfull or newter', or simply 'Protestant'. ${ }^{110}$ Still more minimally and pragmatically, a 1582 listing of the nobility and gentry of England arranged the notables under three headings 'Catholic', 'Prot[estant]' and 'indifferent'. 11

${ }^{106}$ William Whitaker, An Answere to a Certeine Booke, Written by M. William Rainolds (London, 1585, STC 25364), 44.

${ }_{107}$ Abbot, Reasons which Doctour Hill hath brought, 81.

108 Mary Bateson (ed.), 'A Collection of Original Letters from the Bishops to the Privy Council, 1564', in Camden Miscellany, Vol. 9 (Camden Society, ns, 53, London, 1893).

109 NA, SP $15 / 21$, fo. 266 r.

${ }^{110}$ NA, SP $15 / 21$, fos. $178 \mathrm{r}-\mathrm{v}$.

${ }^{111}$ NA, SP $12 / 157$, fo. $196 \mathrm{r}$. It is possible more broadly around this time to detect a growth of use of the word attending the business of government, particularly the clandestine world of countering the Catholics. Thus Walsingham received secret advertisement in 1581 that no fewer than 50 Englishmen 'aswell papistes as protestantes' were considered in Rome and other places to be spies (NA, SP 12/153, fo. $4 \mathrm{r}$ ). Another secret advertisement that same year outlined the tricks papists abroad used 'towardes protestantes for to make them... revolt from ther fayth' (Cal. St. P. Dom. 1581-1590, no. 84), while an informant wrote to Walsingham in 1584 to report how popish books, including the Rheims New Testament and Persons' Book of

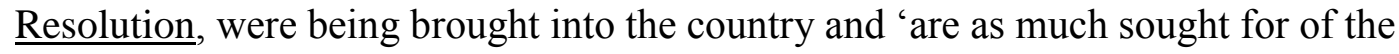
protestantes as papistes' (NA, SP 12/108, fol. 75r). 
Designation as 'Protestant' served to define trustworthy and responsible membership of the English Church; it also helped to secure its ideological foundations, as English reformers increasingly projected the term back into their own history. It was a theological and propaganda imperative for the reformers to identify the lineage of a true Church which had always stood firm against Rome, and for this purpose 'Protestant' was a useful item in the theological tool-kit. ${ }^{112}$ Deployment was not indiscriminate: Foxe, for example, saw the Hussites as 'Protestants', though not the Lollards, albeit he did gloss his account of the 1509 persecution in London diocese with the marginalium: 'the profession of the Protestants no new doctrine'. Some did not quite measure up. Foxe thought that the immediate pre-Reformation victim of clerical malice, Richard Hunne, 'semed rather halfe a Papist: at least no full Protestant, for that hee resorted dayly to Masse, and also had his beades in prison with hym, after the catholique maner'. ${ }^{113}$ Nonetheless, Catholics were alert to what they regarded as semantic sleight of hand. William Rainolds accused Foxe of calling Protestants any 'sect which himself best liked', and he pointed out, with some justification, that the religion of Jan Hus and Jerome of Prague was 'far more differing from the Protestante then from the Catholike'. ${ }^{114}$ The absurdity of claiming the Waldenses, Wyclif, or Hus as Protestants was a regular Catholic critique. ${ }^{115}$ William Fulke had to defend himself from the charge that he had named 'Ziska \& Procopius, and George king of Bohemia defenders of $\mathrm{y}^{\mathrm{e}}$ Protestants an 100. yeares before the name, \& much more the religion of $\mathrm{y}^{\mathrm{e}}$ Protestants was coined'. He protested that it was unreasonable to suppose that 'their religion might not be before $\mathrm{y}^{\mathrm{t}}$ name was vsed to cal them by'. ${ }^{116}$ Parsons, chronicling the pirating of Catholic books from which he himself had suffered, complained of heretical editors taking 'the holie meditations of S. Augustin and Saint Bernard... and making thos blessed men to

\footnotetext{
${ }^{112}$ See Thomas Betteridge, Tudor Histories of the English Reformations, 1530-83 (Aldershot, 1999).

${ }^{113}$ Foxe, Acts and Monuments (1563), 251-9; [1576], 766; [1570], 856, 938.

${ }_{114}$ Rainolds, Refutation of Sundry Reprehensions, 17, 90-1.

${ }^{115}$ A Historical Relation of the Conversion of Sir Tobie Matthew, ed. Arnold Harris Mathew (London, 1904), 126; Fisher, Reply Made unto Mr. Anthony Wotton, 304-5; William Wright, A Treatise on the Church (Saint-Omer, 1616, STC 26049), passim. ${ }^{116}$ William Fulke, A Reioynder to Bristows Replie in Defence of Allens Scroll of Articles and Booke of Purgatorie (London, 1581, STC 11448), 283.
} 
speake like protestantes'. ${ }^{117}$ There were occasional grandiose claims, none perhaps more so than the suggestion in John Bridges' translation of Rudolf Gwalter's sermons on $\underline{\text { Acts}}$, that the Cypriot Mnason, who accompanied Paul on his last journey to Jerusalem was 'an olde disciple or protestant'. ${ }^{118}$

Much more commonly, however, godly Elizabethans, like twentieth-century historians, applied the label Protestant to people who never used it of themselves, the evangelicals of Henry VIII's reign. This was the habit of John Foxe, and also of those supplying him with reminiscences and information, like Ralph Morice and John Louthe. ${ }^{119}$ By the time a volume of his writings was published in 1580, John Hooper had become 'that most learned, godlie, faithfull, zelous, constant, and in all points praise worthie Protestant'. ${ }^{120}$ Noting that the king and council had issued in 1537 a 'Protestation' against Paul III's convoking of the Council of Mantua at the same time as the German Protestants had rejected its authority, Andrew Willet surmised that 'the name of Protestants... tooke beginning in England in King Henry the eights daies'. ${ }^{21}$ There is also a particularly revealing paratextual moment in the second (1587) edition of that emblematic Elizabethan publication, Holinshed's Chronicles. Writing about the 1530s and 40s, one of the contributors, the antiquarian Francis Thynne, habitually referred to Cranmer's conservative opponents as the 'pontificals' and to his supporters as 'the evangelicals'. Modern historians might approve of this nomenclature, but the text's general editor, the godly Abraham Fleming, clearly did not, asterisking every occurrence of the two terms with the marginal translations 'papists', and 'protestants or gospellers'. 122

\footnotetext{
${ }^{117}$ Robert Parsons, A Christian Directorie ... with Reprofe of the Corrupt and Falsified Edition of the Same Booke Lately Published by M. Edm. Buny, (Rouen, 1585, STC 19354.1), fo. 9v.

${ }^{118}$ Rudolf Gwalther, An Hundred, Threescore and Fiftene Homelyes or Sermons, uppon the Actes of the Apostles, tr. John Bridges (London, 1572, STC 25013), 767.

${ }^{119}$ For example, Foxe [1563], 607; [1570], 1407; Narratives, 25, 251. In the 1583 edition of Acts and Monuments (p. 872), Foxe included a brief note on 'The name of Protestantes, how it first beganne'.

${ }^{120}$ Certeine Comfortable Expositions of the Constant Martyr of Christ, M. Iohn Hooper (London, 1580, STC 13743), fo. iir.

${ }^{121}$ Willet, Synopsis Papismi, sig. B2r. Cf Foxe [1583], 1083.

${ }^{122}$ Holinshed's Chronicles, ed. Henry Ellis, 6 vols. (London, 1807-8), iv, 737, 738, 740,748 .
} 
Later Elizabethan England had become in some sense 'Protestant'. Yet it would be a mistake to regard the word as the marker of a stable and settled religious 'identity', its widespread adoption a sign of the maturation and embedding of a unitary Reformation project. For the utility and popularity of the label Protestant was undoubtedly galvanized in these years by the arrival on the scene of a new group and a new word to describe them (though it is a moot point which came first): 'Puritans'. As we noted at the outset of this essay, the polemical and cultural significance of the name 'Puritan' has become a familiar historical theme in the social and political history of Elizabethan religion. But the semantic and conceptual relationship between the categories of 'Puritan' and 'Protestant' has not been a prominent theme in the modern scholarship. Closer attention to this relationship, however, serves not only to account for the late sixteenth-century rootedness of the latter term, but encourages further recognition of the highly political and ideological character of religious taxonomy in these years.

Once again, Catholics were instrumental in the process. We do not know for certain who first thought up the insulting label 'Puritan' in the mid-1560s to describe those dissatisfied with the pace of official reform, but it is quite probably a Catholic coinage: the earliest textual sighting may be in Thomas Stapleton's A Fortresse of the Faith in $1565 .{ }^{123}$ The reformer Thomas Wilcox claimed in 1581that Nicholas Sander was the 'first deviser' of this 'word of a doubtful signification', seeking thereby to tar sincere Christians with the brush of the ancient Novatian heresy (that there was no hope of repentance for those who sinned after baptism). ${ }^{124}$ Whatever the truth of this, it is clear that Catholic writers eagerly embraced the term Puritan as yet further evidence of the intrinsic fissiparousness of heresy, starting to identify Lutherans, Calvinists, Protestants, and Puritans as the adherents of separate religions. ${ }^{125}$ The

${ }^{123}$ Thomas Stapleton, A Fortresse of the Faith First Planted Amonge us Englishmen (Antwerp, 1565, STC 23232), fo. 134v.

${ }^{124}$ T[homas] W[ilcox], The Unfouldyng of sundry untruths and absurd propositions (London, 1581), 80-3. A German visitor to England in 1598 was also told that 'they were first named Puritans by the Jesuit Sanders': W. B. Rye (ed.), England as Seen by Foreigners in the Days of Elizabeth and James the First (London, 1865), 111. ${ }^{125}$ A point made, with illustrations, by Collinson, 'Antipuritanism', 19-20. See also Jean d' Albin de Valsergues, A Notable Discourse ... with an Offer Made by a Catholike to be a Learned Protestant tr. Edward Rishton and William Allen (Douai 
imprisoned former abbot of Westminster, John Feckenham, in a statement recorded by the bishop of Ely's chaplain, gave as his reason for refusing to take part in prescribed worship 'the score of the divisions amongst us; for as he goes on, some of the English are Protestants, some Puritans, and some of the Family of Love. ${ }^{, 126}$ Robert Parsons claimed in 1580 that England contained four religions, 'distinct both in name, spirite, and doctrine: that is to say, the Catholickes, the Protestants, the Puritanes, and the howsholders of Love. ${ }^{127}$

This was polemical point-scoring, but the notion that there were at least two important sub-categories of heresy in England seems to have been a real perception on the part of Catholic dissidents, and one which directly dictated their pastoral and political strategies. Thomas Cottam, the Jesuit priest tried alongside Campion in 1581, had been found to have in his possession a tract advising ' how you ought to demean yourself in every sort of company, whether it were of Protestants or Puritans, and what speeches you should use to convert them both' ${ }^{128}$ Soon afterwards, Persons wrote about the English situation to Alfonso Agazzari, Jesuit rector of the English College in Rome, and revealed that 'the puritans' and 'the Calvinists' were now bitter enemies. ${ }^{129}$ A 1592 intelligence report on Catholic plotters reported their firm belief that the realm was 'generally devided especially for matter of religion into three mighty factions of Catholikes, Protestants and Puritans'. ${ }^{130}$ In the late 1580 s, Catholic agitators like Charles Paget were avidly reporting news of divisions in the Council

[i.e. London], 1575, STC 274), fo. 65v; William Allen, An Apologie and True Declaration of the Institution and Endevours of the Two English Colleges (Rheims, 1581, STC 369), fo. 20v; Martin, New Testament, 532; Rainolds, Refutation of Sundry Reprehensions, 86-7.

${ }^{126}$ Strype, Annals, i. Part ii. 528-9.

${ }^{127}$ Parsons, Brief Discours, fo. $\$ 3$ r. See also Parsons (?), An Epistle of the Persecution of Catholickes in Englande (Douai [ie Rouen], 1582, STC 19406), 33. Other examples of Catholic works distinguishing Protestants from Puritans: Conversion of Sir Tobie Matthew, 133; Michael Walpole, A Briefe Admonition to All English Catholikes (Saint-Omer, 1610, STC 24992), 72-3; George Musket, The Bishop of London his Legacy (Saint-Omer, 1623, STC 18305), 246; William Rainolds, A Treatise Conteyning the True and Apostolike Faith of the Holy Sacrifice and Sacrament (Antwerp, 1593, STC 20633), 315; Anderton, Non-Entity of Protestancy, 97-8; Anderton, Progenie of Catholicks, bk 3, p. 32 (Puritans were become 'a sect so different and adverse' from Protestants that 'a distinction of names is necessarily required.')

${ }^{128}$ Richard Simpson, Edmund Campion: A Biography (London, 1896), 425.

${ }^{129}$ Leo Hicks (ed.), Letters and Memorials of Father Robert Persons, S.J., Vol. I (to 1588), Catholic Record Society, 39 (London, 1942), 180.

${ }^{130} \mathrm{NA}$, SP $12 / 243$, fo. 303. 
'about the protestantes and puritans', and at the time of the Essex rebellion in 1601, Catholic supporters of the earl were spreading the rumour that he was really one of theirs, but hid his religion for reasons of policy, so that 'both puritans \& protestantes might be drawne to take his parte.' 131

True to the nature of English Catholicism in this period, the instinct to distinguish 'Protestants' from 'Puritans' had an international dimension. Shortly after his return from England in November 1604, Philip III's envoy, Juan Fernandez de Velasco, told his master that the Puritans and Protestants constituted two sects, and that 'the Protestants are not so distant towards the Catholics nor are they as hostile as the Puritans. ${ }^{132}$ His successor, Count Gondomar, later expanded the diagnosis with the confident but spurious statistical precision that frequently beguiled contemporary observers of the socio-religious scene. One twelfth of the English people were true Catholics, and two-twelfths were schismatics who were Catholic at heart. A further three-twelfths were well-disposed to Catholics, without caring very much about religion (these 'can be called atheists'). Of the remaining fifty per cent of the population, two-thirds, or 1,200,000 people, were Protestants, 'more moderate heretics'. Gondomar added, gratuitously and inaccurately, that they were so-called 'because they protested at the Diet of Augsburg on behalf of some propositions of Luther in 1530'. The other third were Puritans, who 'adhere closely to the beliefs of Calvin'. Their number was 600,000 , though 'they are gaining people every day from the Protestants'. ${ }^{133}$

As these despatches suggest, the identification of Protestants and Puritans was closely connected to the calculation of advantage to the Catholic cause in England. Particularly after the accession of James I, Catholics had a vested interest in seeking to essentialize Puritanism as a separate (and seditious) religion, both to underline their own claim to toleration in an already pluralistic religious landscape, and to burnish their credentials as (by comparison) loyal and trustworthy subjects. ${ }^{134}$ The Jesuit Thomas Fitzherbert thus put to Lancelot Andrews in 1613 the unlikely accusation that in the matter of the king's supremacy he had 'turned puritan', and was therefore

${ }^{131}$ NA, SP 15/ 31, fos. 33r, 41r ; SP 12/278, fol. 110r.

${ }^{132}$ Albert J. Loomie (ed.), Spain and the Jacobean Catholics, 2 vols, Catholic Record Society, 64, 68 (1975-78), i, 35-6.

${ }^{133}$ Ibid., ii, 29.

${ }^{134}$ I explore this theme further in 'John Calvin and the English Catholics, c. 15601640’, Historical Journal, 53 (2010). 
'neyther good English Protestant, nor yet good subiect. ${ }^{, 135}$ The instinct quickened as divisions within the Church of England patently widened after the accession of Charles I. The title of a Catholic work like Puritanisme the Mother, Sinne the Daughter seems deliberately calculated to appeal to the ascendant Laudians of the mid-1630s. Its author was careful to distinguish between the Puritan and 'the moderate and more learned Protestant', 'temperate and sober Protestants'. ${ }^{136}$ For the Jesuit John Floyd, it was axiomatic that 'all men know' the name of Protestant properly to signify 'that part of the pretended English Reformation, which is contradistinct from Puritans, and opposite against them'. The English Protestant Church was, he conceded, 'the most moderate of all' that had separated from Rome. $^{137}$

In its mature late Elizabethan and Jacobean form, therefore, there are good arguments for regarding 'Protestant' as the principal antonym, not of Catholic, but of Puritan. Recognising that the Protestant/Puritan dichotomy was to a considerable extent a Catholic construction, some authors, particularly from the godly wing of the Church, refused indignantly to recognise it. ${ }^{138}$ William Fulke rebuked Richard Bristowe in 1580: 'if hee recken the Puritanes for such as bee no Protestantes, let them aunsweare for them selves. If he calles them Puritanes which desire to have the Church thorowly reformed, there is no such dissention betweene them, but that they all agree in the Articles of Faith, maintayne brotherly concorde one with an other, notwithstanding in diversitie of opinions concerning the matters and manner of reformation. ${ }^{139}$ A similarly firm line was taken with Robert Persons by the godly Percival Wiburn: 'we once make but one religion of those $\mathrm{y}^{\mathrm{t}}$ you cal protestants \& Puritans'. ${ }^{140}$ Sir Francis Hastings termed the papists' habit of calling some men Protestants and some Puritans 'a devised distinction', a 'tricke of cunning'. ${ }^{141}$

\footnotetext{
135 Thomas Fitzherbert, An Adioynder to the Supplement of Father Robert Persons his (Saint-Omer, 1613, STC 11022), 329.

${ }^{136}$ B. C., Puritanisme the Mother, Sinne the Daughter (Saint-Omer, 1633, STC 4264), 'Epistle Dedicatory'.

${ }^{137}$ John Floyd, The Church Conquerant over Humane wit (Saint-Omer, 1638, STC 11110), 134.

${ }^{138}$ Some non-puritan authors were similarly concerned not to let Catholics exploit divisions among the reformers: Milton, Catholic and Reformed, 45-6.

${ }^{139}$ Fulke, Retentive, 62.

${ }^{140}$ Wiburn, Reproofe of M. Howlets Untimely Shreeching, fo. $15 \mathrm{r}$.

${ }^{141}$ Francis Hastings, An Apologie or Defence of the Watch-Word (London, 1600, STC 12928), 13.
} 
Yet if the 'invention' of Puritanism was to a considerable extent kick-started by papists, it was taken to full throttle by members of the reformed church itself. As Patrick Collinson has convincingly argued, the fully-formed stereotype of the Puritan belongs not to the 1560s, but to the last decade of the sixteenth century, and reflects the growing pugnacity of an 'anti-Puritan' tendency within the Church of England in the wake of the failed Presbyterian movement and the furore over the Marprelate tracts. ${ }^{142}$ Historians have long wrestled with the problem of generating appropriate labels to designate those members of the Church of England who supplied the other half of what Collinson famously dubbed the 'stressful relationship' that defined Puritanism. ${ }^{143}$ Non-puritans and anti-puritans have been variously described as Anglicans, credal Calvinists, conformists (some of them 'avant-garde conformists'), or even Anglo-Catholics. ${ }^{144}$ None of these terms - least of all Anglican - would have been readily recognized as proper nouns by the subjects to whom they refer. ${ }^{145}$ Peter Lake has defended this 'small outbreak of neologism' on the grounds that the identifications in question were often 'unstable ideological syntheses, political coalitions and expedients', liable to fracture and realignment. ${ }^{146}$ It is important for historians to remember that there could have been no such thing as a single, coherent

\footnotetext{
${ }^{142}$ Collinson, 'Ecclesiastical Vitriol'; 'Ben Johnson's Bartholomew Fair'; 'Antipuritanism', 22-7.

${ }^{143}$ Collinson, Birthpangs, 143.

${ }^{144}$ Anglican: John F. H. New, Anglican and Puritan: The Basis of their Opposition, 1558-1640 (London, 1964); Richard L. Greaves, Society and Religion in Elizabethan England (Minneapolis, 1981). For credal Calvinists, Peter Lake, 'Calvinism and the English Church 1570-1635', Past and Present, 114 (1987), 32-76; Avante-garde conformity: Lake, 'Lancelot Andrewes, John Buckeridge, and Avant-garde Conformity at the Court of James I', in Linda Levy Peck (ed)., The Mental World of the Jacobean Court (Cambridge, 1991). Debora Shuger, 'A Protesting Catholic Puritan in Elizabethan England', Journal of British Studies, 48 (2009) makes the case for a wide spectrum of 'Anglo-Catholic' sentiment in the Elizabethan Church. 'Conformist' is the default position of much recent scholarship, see Milton, Catholic and Reformed, 8-9; Peter Lake and Michael Questier (eds.), Conformity and Orthodoxy in the English Church, c. 1560-1660 (Woodbridge, 2000); Charles W. A. Prior, Defining the Jacobean Church: The Politics of Religious Controversy, 16031625 (Cambridge, 2005).

${ }^{145}$ The earliest recorded instance of Anglican appears to be James VI's 1598 assurance that he had no intention of imposing 'papistical or Anglican' bishops on the Church of Scotland: Diarmaid MacCulloch, 'The Latitude of the Church of England', in Kenneth Fincham and Peter Lake (eds.), Religious Politics in Post-Reformation England (Woodbridge, 2006), 42.

${ }^{146}$ Lake, 'Historiography of Puritanism', 356.
} 
'non-puritan identity' in Elizabethan and early Stuart England. ${ }^{147}$ Yet many contemporaries had a strong vested interest in the polemical construction of just such an entity, and for these purposes they had a potent instrument to hand, with 'Protestant' offering a straightforward and familiar alternative to the novel and rebarbative name of Puritan.

Thus, at the moment of its widespread adoption, the nomenclature of Protestant was not necessarily a bland and consensual underwriting of a cohesive reformed religious culture. The dualism of Protestant/Puritan might function in the same way as that of Catholic/Papist, to effect exclusion from an identity the excluded themselves wished to claim. The strategy is embryonically evident, for example, in $\underline{A}$ Defence of the Government Established in the Church of Englande, an inflated contribution to the Presbyterian controversy of the late 1580 s by the dean of Salisbury, John Bridges, and the book that supplied the original target for the Marprelate tracts. ${ }^{148}$ Bridges complained that 'our brethren', under pretence of rooting out papistry, were targeting 'poore ministers of gods word', whom they denounced as Canaanites 'bee they neuer so zealous protestantes'. The presbyterian project was anathema, not only to the Queen, but to 'a great number besides, which thinke themselues as sounde Protestantes, and as good subiects as you'. Bridges further attacked the Puritans for impugning the integrity of ministers who earlier in their careers had perforce been popish priests, but were now 'good and sound converted protestants'. And he rebutted puritan attacks on general convocations as 'stuffed full of popish and prophane chancellors, and other lawyers'. Critics should name any such members they could prove to be popish, or refrain from 'too uncharitable, too unprotestant-like a sclaunder'. ${ }^{149}$ A number of 'anti-Martinist' writers were soon following the cue in the literary backlash against the Marprelate tracts. Richard Harvey contrasted 'earnest protestants', who studied to reform their own lives, with the hypocritical puritans, who 'like bad huswifes flie abroad, and search out publike imperfections', while John Lyly scoffed that anyone who should 'come short of their

${ }^{147}$ A point ably made by Anthony Milton, 'Religion and Community in Pre-Civil War England', in Nicholas Tyacke (ed.), The English Revolution c. 1590-1720

(Manchester, 2007), 71-3.

${ }^{148}$ See Patrick Collinson, 'English Reformations', in Michael Hattaway (ed.), $\underline{A}$ Companion to English Renaissance Literature and Culture (Oxford, 2000), 38.

${ }^{149}$ John Bridges, A Defence of the Government Established in the Church of Englande (London, 1587, STC 3734), 7, 39, 99, 1281, 1297-8. 
religion, why he is but a colde Protestant, hee must bee pluckt out to the length of a Puritane'. ${ }^{150}$ The deathbed confession which Thomas Nashe placed in the mouth of Martin Marprelate had him admit to slandering 'some to be Papists, whom I knew to be sound Protestants'. 151

The antithesizing of Protestant and Puritan entered the cultural and political blood-stream of later Elizabethan and Jacobean England. A correspondent hostile to the earl of Leicester complained in 1584 of his stirring up the 'protestantes' and 'puritanes' against each other. ${ }^{152}$ A 1590 Paul's Cross sermon by Roger Hacket itemised 'our protestantes' and 'our puritanes' among the groups who needed to be wary of Catholic plotting. ${ }^{153}$ In George Chapman's play, Eastward Hoe, a prisonkeeper declares that he has had 'all sorts of men i' the Kingdome, under my Keyes, \& almost of all Religions i' the land, as Papist, Protestant, Puritane, Brownist, Anabaptist' ${ }^{154}$ A real prisoner, the recusant John Rigbie, was required to answer on his arrest in 1600, 'Art thou a Papist, a Protestant, a Puritan, or what religion art thou of?' 155 In the clergyman Oliver Ormerod's Picture of a Puritane (1605), a 'Protestant' and a 'Puritane' debate issues of the day to the discomforting of the latter, while the 'plaine Protestant' and the 'precise Puritan' are similarly contrasted as adversarial types in a late Elizabethan gentry commonplace book from the North West of England. ${ }^{156}$ Harrington, in his tract on the succession, defended his use of the terms papist, Puritan, Protestant as a matter of 'division and distinction', and because these were the names by which they were now 'most notoriously knowen' ${ }^{157}$ The focus of Harrington's hopes for the succession, James I, seemed also to accept the validity of

${ }^{150}$ Richard Harvey, Plaine Percevall the Peace-Maker of England (London, 1590, STC 12914), 14-15; John Lyly, Pappe with an Hatchet Alias, a Figge for my God Sonne (London, 1589, STC 17463), 'To the Reader'.

${ }^{151}$ Thomas Nashe, Martins Months Minde that is, a Certaine Report, and True Description of the Death, and Funeralls, of Olde Martin Marreprelate (London, 1589, STC 17452), sigs. F2v-F3r.

152 NA, SP 15/28/2, fo. 162 r .

${ }^{153}$ Roger Hacket, A Sermon Needfull for Theese [sic] Times (London, 1591, STC 12589), sig. A1v.

${ }^{154}$ George Chapman, Eastward Hoe (London, 1605, STC 4971), H4r.

${ }^{155}$ Clancy, 'Papist-Protestant-Puritan', 242.

${ }^{156}$ Arnold Hunt, 'Ormerod, Oliver (d. 1626)', ODNB; Folger Shakespeare Library [F41]. V.a.399, fos. 18v ff. I owe this reference to Alec Ryrie.

${ }^{157}$ Harrington, Tract on the Succession, 5, 33. 
the distinction, refuting in 1609 Cardinal Bellarmine's suggestion that 'I was a Puritane in Scotland, and an enemie to Protestants'. ${ }^{158}$

\section{VIII}

Over the course of the English Reformation the assigning of names of division and distinction became a deeply grounded social habit. In this wider context, Sir John Harrington's 1602 self-designation as a 'Protesting Catholic Puritan' seems not so much an attempt to assert a distinctive new identity as a playful and ironic recognition of the extent to which religious labels had come to define and determine the contemporary scene, a back-handed tribute to their immense cultural and ideological importance. ${ }^{159}$ This essay has attempted to demonstrate that the labelling process, studied so intensely for the particular case of Puritanism, has a much broader claim on our attention. For from the outset, the polemical construction and deconstruction of denominated identities was critical to the progress and development of the Reformation in England.

Historians of the English Reformation - myself included - have often been premature, perhaps even careless, in the way they have unreflectively characterized their subjects as 'Protestants' from a relatively early date. Though he did not mean it in quite this sense, Christopher Haigh was probably correct to state that, even by around 1580, the Reformation in England had not yet created 'a nation of Protestants'. ${ }^{160}$ It would appear, in fact, that many English adherents of the Reformation may have become proud to be Protestant in the sixteenth century on something like the same timescale as English homosexuals became glad to be gay in the twentieth: a full half-century or more from the first recorded citations of the word

\footnotetext{
${ }^{158}$ James I, The Workes of the Most High and Mightie Prince, Iames... King of Great Britaine (London, 1616, STC 14344), 305. James described his own position as that of 'such a Catholike Christian as beleeveth the three creeds' (302).

${ }^{159}$ Harrington, Tract on the Succession, 108; pace the interpretation of Shuger, 'Protesting Catholic Puritan'.

${ }^{160}$ Haigh, English Reformations, 280.
} 
in an ironic or derogatory context to its increasingly confident ownership by members of a self-defining group. ${ }^{161}$

Historians do not necessarily have to stop using the word Protestant, any more than out of theological scruple they should cease calling adherents of the papacy Catholics, or shun the word Puritan because neither contemporaries nor moderns have been able to agree on a precise definition of what it meant. There is, in any case, no baggageless alternative designation to hand. Supporters of the Reformation, through the middle decades of the sixteenth century and beyond, variously termed themselves Christians, evangelicals, catholics, gospellers - all value-laden terms with their own histories of polemical deployment and counter-appropriation.

Yet there is an imperative to build into our historical narratives a keener awareness that names are not inherent properties, fixed points from which description and analysis safely proceeds, and that their changing meanings are not merely passive markers or reflections of developing social realities. Designations like 'Protestant', and the ideological and cultural capital which they represented, were subject to continuous and contentious negotiation in the sixteenth and early seventeenth centuries, on the page and on the ground. As Peter Lake has observed, in using such terms of identity, historians need to be 'as self-conscious as possible about their contemporary derivations, often convoluted polemical histories, and sometimes complex, and contradictory, meanings and connotations. ${ }^{162}$

Much of the most interesting scholarship on the Reformation in Europe over the past three decades has concerned itself with the increasing 'confessionalization' of states and communities in the later sixteenth and early seventeenth centuries. ${ }^{163}$

${ }^{161}$ The OED gives its first (albeit ambiguous) examples of 'gay' meaning homosexual from the 1920s. Tom Robinson's song 'Glad to be Gay' was the anthem of a newly assertive Gay Rights Movement in the 1970s.

${ }^{162}$ Peter Lake, 'Religious Identities in Shakespeare's England', in David Scott Kastan, (ed.), A Companion to Shakespeare (Oxford, 1999), 59.

${ }^{163}$ The foundational works here are those of Heinz Schilling and Wolfgang Reinhard. Schilling: Konfessionskonflict und Staatsbildung (Gütersloh, 1981); Religion, Political Culture and the Emergence of Early Modern Society (Leiden, 1992); 'Confessional Europe', in Handbook of European History 1400-1600, ed. Thomas A. Brady, Heiko O. Oberman and James D. Tracy, 2 vols., (Leiden, 1995), ii; (ed.), Die reformierte Konfessionalisierung in Deutschland: Das Problem der 'Zweiten Reformation' (Gütersloh, 1986); Reinhard: 'Gegenreformation als Modernisierung? Prolegomena zu einer Theorie des konfessionellen Zeitalters', Archiv für Reformationsgeschichte, 68 (1977); 'Reformation, Counter-Reformation and the Early Modern State: a Reassessment', Catholic Historical Review, 75 (1989); and 
England has not generally been seen as a polity to which the classic stateconfessionalization paradigm pertains, largely on the grounds that under Elizabeth and her successors the campaigns for political conformity and for purified religious orthodoxy did not go smoothly hand-in-glove. ${ }^{164}$ Nonetheless, a growing interest in the themes of 'self-confessionalization' and 'confessionalization from below' holds the potential to reintegrate England into the debate in interesting ways. ${ }^{165}$ In none of the main discussions of confessionalization, however, has the politics of language and labelling played a particularly central role. Yet as this case-study has suggested, its reinscription may be seriously overdue. An alertness to the role of words and language helps to reveal the limitations of any narrowly 'internalist' history of confessionalformation. Protestant England was, to a considerable extent, named in concert with its Catholic opponents - recognition of which fact adds momentum to an ongoing and still incomplete effort to re-insert the history of Catholics into mainstream narratives of post-Reformation history. ${ }^{166}$

Understanding the potency and potential, as well as the protean character, of 'Protestant' within its conceptual field of related terms may also help with the fraught business of elucidating the fundamental character of the Elizabethan and Early Stuart Church (Reformed? Uniquely hybrid? Consensually Calvinist?), and of mapping some of its key fissile and centrifugal tendencies. ${ }^{167}$ Protestant was a term, depending

Heinz Schilling (eds.), Die Katholische Konfessionalisieung (Gütersloh and Münster, 1995). A recent guide to the extensive historiography is provided by Ute LotzHeuman, 'Confessionalization', in David M. Whitford (ed.), Reformation and Early Modern Europe: A Guide to Research (Kirksville, MO, 2008).

${ }^{164}$ Andrew Pettegree, 'Confessionalization in North Western Europe', in Joachim Bahlcke and Arno Strohmeyer (eds), Konfessionalisierung in Ostmitteleuropa (Stuttgart, 1999); Patrick Collinson, 'The Politics of Religion and the Religion of Politics in Elizabethan England', Historical Research, 82 (2009).

${ }^{165}$ Lotz-Heuman, 'Confessionalization', 146-51. For some preliminary soundings, see Tom Betteridge, Literature and Politics in the English Reformation (Manchester, 2004); Marshall, Religious Identities; Marshall, '(Re)defining the English Reformation', 584-6.

166 The combined efforts of Peter Lake and Michael Questier have been notable in this regard. See their Antichrist's Lewd Hat; Conformity and Orthodoxy; and jointly written article, 'Puritans, Papists, and the "Public Sphere" in Early Modern England: the Edmund Campion Affair in Context', Journal of Modern History, 72 (2000). See also Questier's Catholicism and Community in Early Modern England (Cambridge, 2006).

${ }^{167}$ Some notable works here are Collinson, Religion of Protestants; Nicholas Tyacke, Anti-Calvinists: the Rise of English Arminianism c. 1590-1640 (Oxford, 1987); Lake, 'Calvinism and the English Church'; Peter White, Predestination, Policy and 
on context and configuration of synonyms and antonyms, that allowed variously of anti-Catholic, anti-Calvinist and anti-formalist constructions. To some, it expressed solidarity with co-believers abroad; to others it came ultimately to be valued for its utility in designating the adherents of a national Church that was not Zwinglian, Lutheran, nor (unproblematically) Calvinist. But its magnetically polarizing relationship with the category of 'Puritan' warns against any over-ready identification of a broad 'Protestant' middle ground as the default position of English religious culture. Its history challenges the convention to be found in much historical and sociological writing that identity-formation comes about through dialectical engagement with a single 'other" ${ }^{\text {' }}$, for the range of others implicated in the cultural transplanting and incubation of the word 'Protestant' was, as we have seen, remarkably fluid and diverse.

Protestant is the word that came to express the religious and political essence of what happened to England in the sixteenth century. But it was a word no one had consciously chosen for the purpose, and that never achieved instantiation in any of the official statements of Church or State. ${ }^{169}$ Through to 1600 and beyond, its meanings remained defiantly plastic and open to manipulation. Its progress was contested at every stage, and the impetuses for its adoption and application came spasmodically 'from above' and 'from below'. ${ }^{170}$ It is, in short, a perfect metaphor for the uncoordinated and unexpected character of the English Reformation itself.

Polemic: Conflict and Consensus in the English Church from the Reformation to the Civil War (Cambridge, 1992); Milton, Catholic and Reformed; Prior, Defining the Jacobean Church.

${ }^{168}$ For example, Laurence Jay Silberstein and Robert L. Cohn (eds.), The Other in Jewish Thought and History (New York, 1994); I. B. Neuman, Uses of the Other: the 'East' in European Identity Formation Manchester, 1999); Elizabeth Le, The Spiral of 'Anti-Other Rhetoric': Discourses of Identity and the International Media Echo (Amsterdam, 2006); Yirmiyahu Yovel, The Other Within: The Marranos: Split Identity and Emerging Modernity (Princeton, 2009).

169 'Protestant' is not to be found in the sixteenth century in any parliamentary statute, the Articles of Religion, the Book of Common Prayer, the Homilies, or the Royal Injunctions (or, indeed, the complete works of Shakespeare).

${ }^{170}$ These categories of analysis are developed in a classic survey: Christopher Haigh, 'The Recent Historiography of the English Reformation', Historical Journal, 25 (1982). 